\title{
REVIEW
}

\section{Closing the door to human immunodeficiency virus}

\author{
Yuanxi Kang $^{1^{*}}$, Jia Guo ${ }^{1^{*}}$, Zhiwei Chen $^{1,2 \bowtie}$ \\ ${ }^{1}$ AIDS Institute and Department of Microbiology of Li Ka Shing Faculty of Medicine, The University of Hong Kong, 21 Sassoon \\ Road, Pokfulam, Hong Kong SAR, China \\ ${ }^{2}$ Research Center for Infection and Immunity, The University of Hong Kong, 21 Sassoon Road, Pokfulam, Hong Kong SAR, \\ China \\ $\square$ Correspondence: zchenai@hku.hk
}

Received November 5, 2012 Accepted November 22, 2012

\section{ABSTRACT}

The pandemic of human immunodeficiency virus type one (HIV-1), the major etiologic agent of acquired immunodeficiency disease (AIDS), has led to over 33 million people living with the virus, among which 18 million are women and children. Until now, there is neither an effective vaccine nor a therapeutic cure despite over 30 years of efforts. Although the Thai RV144 vaccine trial has demonstrated an efficacy of $31.2 \%$, an effective vaccine will likely rely on a breakthrough discovery of immunogens to elicit broadly reactive neutralizing antibodies, which may take years to achieve. Therefore, there is an urgency of exploring other prophylactic strategies. Recently, antiretroviral treatment as prevention is an exciting area of progress in HIV-1 research. Although effective, the implementation of such strategy faces great financial, political and social challenges in heavily affected regions such as developing countries where drug resistant viruses have already been found with growing incidence. Activating latently infected cells for therapeutic cure is another area of challenge. Since it is greatly difficult to eradicate HIV-1 after the establishment of viral latency, it is necessary to investigate strategies that may close the door to HIV-1. Here, we review studies on non-vaccine strategies in targeting viral entry, which may have critical implications for HIV-1 prevention.

KEYWORDS HIV-1, entry inhibitor, vaccine, antiretroviral, antibody

\footnotetext{
*These authors contributed equally to the work.
}

\section{INTRODUCTION}

Human immunodeficiency virus type one (HIV-1) is the major etiologic agent of acquired immunodeficiency disease (AIDS) (Barre-Sinoussi et al., 1983). Currently, the estimated number of people living with HIV-1 is about 33.3 million, among which 18.4 million are women and children. Since its inception, HIV-1 prevalence has brought a ponderous burden to human health and world-wide economic development, especially in the developing countries (UNAIDS., 2010). A cheap, safe and effective prophylactic measure, such as vaccine, remains the first priority of HIVIAIDS research. However, the failure of a leading T cell-based AIDS vaccine MRKAd5 in a Phase $2 b$ clinical trial has raised doubts about the feasibility of such types of candidates (Buchbinder et al., 2008). Recently, although the Thai RV144 clinical trial demonstrated an efficacy of $31.2 \%$ (Rerks-Ngarm et al., 2009), it remains unclear when an effective vaccine will be made available for HIV-1 prevention. Other prophylactic strategies, therefore, should be explored urgently as well.

The life cycle of HIV-1 can simply be divided into two major phases: entry phase and post-entry phase. The post-entry phase includes reverse transcription, integration, viral RNA and protein synthesis, packaging and budding. Highly active antiretroviral therapy (HAART), which has been successfully used in reducing AIDS-related deaths in the past 16 years, is usually composed of three antiviral drugs including reverse transcriptase inhibitors (RTI) and protease inhibitors (PI) targeting the post-entry phase (Hammer et al., 1996; Lu et al., 2012). Although successful, there are drug-resistant viruses found against these viral inhibitors (Boden et al., 1999; Luo et al., 2009). Current HAART also fails to eradicate HIV-1 from 
infected people. Viral entry phase has, therefore, become an attractive target for the development of preventive and curative strategies against HIV-1 infection.

The entry of HIV-1 into susceptible cells can be dissected into at least three continuous steps (Fig. 1): (i) HIV-1 initiates its infection by binding of viral envelope protein (Env) to the cluster of differentiation 4 (CD4) receptor, followed by a conformational change in viral glycoprotein 120 (gp120). (ii) As a result, a hidden binding site within the variable loop 3 (V3) on gp120 is exposed, allowing subsequent binding to one of the co-receptors, either $\mathrm{C}-\mathrm{C}$ chemokine receptor type 5 (CCR5) or C-X-C chemokine receptor type 4 (CXCR4). (iii) A further conformational remodeling of gp120 induces a gp41 conformation transition which allows its hydrophobic $\mathrm{N}$-terminus to penetrate host cell, mediates membrane fusion between virus and cell, and release viral RNAs and enzymes into cells (Eckert and Kim, 2001; Pierson and Doms, 2003). Each of these steps has provided a target to develop non-vaccine antiviral strategies including neutralizing antibodies, synthesized peptides and polymers, small molecule inhibitors or gene therapies (Fig. 1). This review will discuss recent progresses of these non-vaccine strategies in targeting the HIV-1 entry phase.

\section{PASSIVE IMMUNIZATION USING NEUTRALIZING ANTIBODIES}

Significant progresses have been made in recent years on the identification of broadly-reactive neutralizing antibodies (bnAbs) targeting to viral Env, CD4 or co-receptors using various techniques (Fig. 1). Critically, passive immunization using these bnAbs has consistently resulted in protection against SHIV/HIV-1 in pre-clinical and clinical trials, suggesting the essential role of bnAbs in antibody-based prophylaxis. Till now, however, these kinds of bnAbs still cannot be elicited in vivo by active vaccination. Although these bnAbs cannot be orally delivered due to the uptake and metabolism issues, improved passive immunization to produce long-lasting bnAbs after delivered by either purified proteins or gene-encoded vectors is likely an attractive approach for HIV-1 prevention. The current understandings on these bnAbs are summarized as follows.

Monoclonal antibody b12 is a recombinant product selected by a phage display technology from a long-term nonprogressor (LTNP) (Barbas et al., 1992). It targets the critical CD4-binding site of gp120 and exhibits a broad spectrum of anti-HIV-1 activity in vitro (Burton et al., 1994; Roben et al., 1994). Crystal structures of b12 and b12-bound gp120 indicate that the long complementary determining region (CDR) $\mathrm{H} 3$ of b12 protrudes into the recessed CD4-binding site of gp120 and maintains an intact bridging sheet of gp120, which determined its broadly neutralizing activity (Saphire et al., 2001; Chen et al., 2009). Passive immunization of b12 confers a dose dependent inhibition of HIV-1 infectivity in severe combined immunodeficiency (SCID) mice transplanted with human peripheral blood lymphocytes (hu-PBL) and in vaginally challenged rhesus macaques (Parren et al., 2001; Veazey et al., 2003). Resistant viruses to b12 were observed by both in vitro selection and in HIV-1-infected patients (Mo et

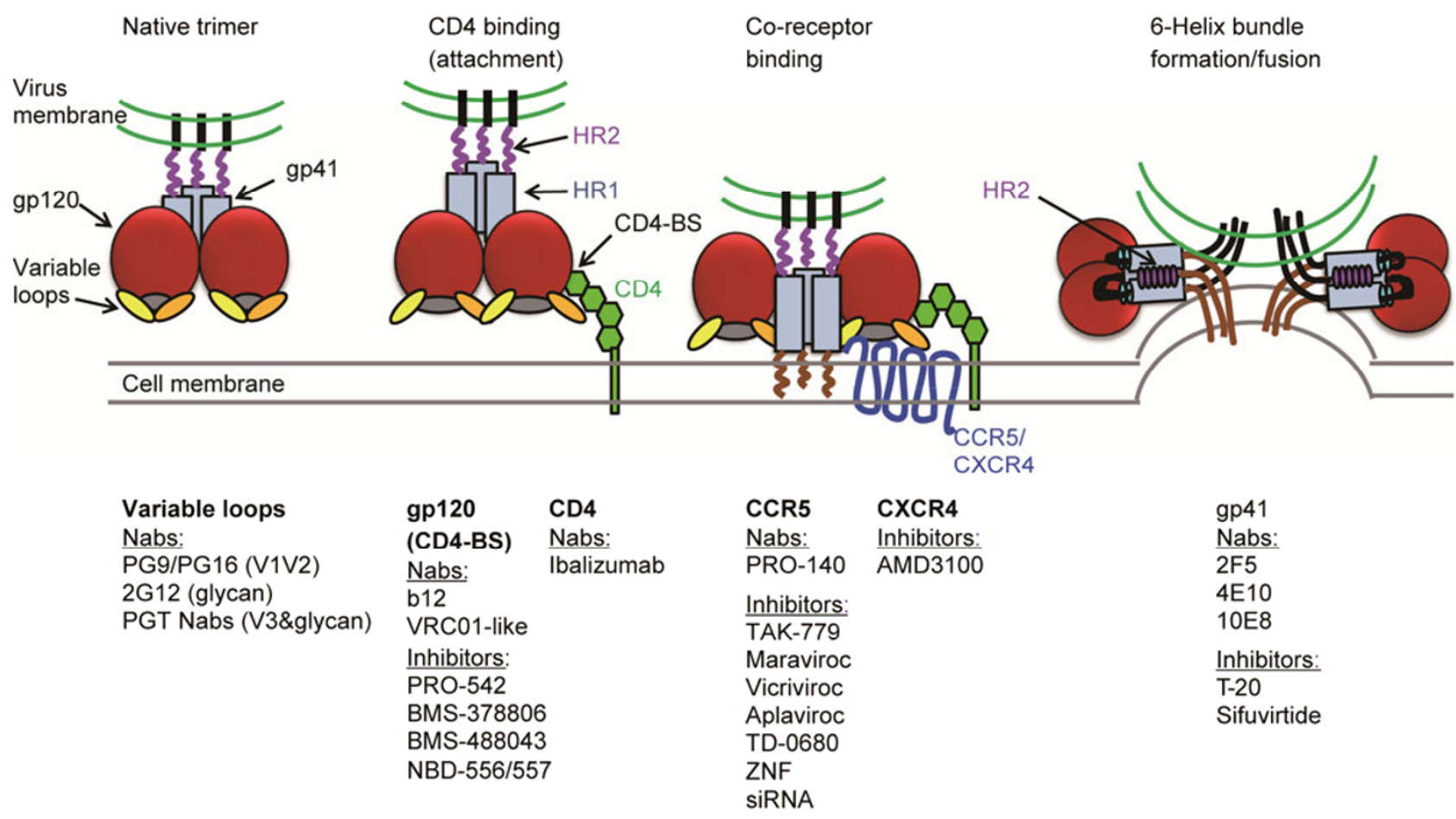

Figure 1. Schematic representation of HIV-1 entry process. The target sites are highlighted corresponding to the steps of viral entry for both neutralizing antibodies and various entry inhibitors. 
al., 1997; Duenas-Decamp et al., 2008). The resistant viruses lost sensitivity to b12 while retaining CD4 for entry, and the mechanism of this viral resistance involved the variations in the b12 contact residues that reside close to the CD4 binding loop (Duenas-Decamp et al., 2008; Wu et al., 2009).

Nabs 2F5 and 4E10 are anti-gp41 monoclonal antibodies generated from HIV-1-seropositive donors with potent and broad anti-HIV-1 activity (Muster et al., 1993; Purtscher et al., 1994). They directly target the membrane-proximal external region (MPER) of gp41 and abolish viral fusion (Zwick et al., 2001a). Similar to b12, 2F5 prevents HIV-1 infection of human dendritic cells (DCs) and the DC-mediated HIV-1 transmission to T cells in vitro (Frankel et al., 1998). Mutations on the recognition epitope of 2F5, ELDKWA, result in neutralization resistance by affecting the binding of $2 \mathrm{~F} 5$ (Purtscher et al., 1996). Passive immunization of 2F5 confers a delayed seroconversion in a chimpanzee intravenous challenge model (Conley et al., 1996). Phase 1 clinical trial has confirmed that $2 \mathrm{~F} 5$ is safe and well tolerated by injection (Armbruster et al., 2002). Consistent data have been obtained from a phase 2 long-term multiple-dose pharmacokinetics study conducted in HIV-1 infected patients (Joos et al., 2006). The antibody-dependent cell cytotoxicity (ADCC) induced by $2 \mathrm{~F} 5$ contributes to the elimination of HIV-1 infected cells (Tudor and Bomsel, 2011). 4E10 recognizes a linear epitope, NWFDIT, located at the C-terminal of the 2F5 epitope (Stiegler et al., 2001). Co-administration of $4 \mathrm{E} 10$ and $2 \mathrm{~F} 5$ results in a synergistic neutralizing effect in vitro (Zwick et al., 2001b). To note, substitutions in the MPER contributed to the resistance to 4E10 (Gray et al., 2008; Nakamura et al., 2010). The safety and tolerability of $4 \mathrm{E} 10$ for clinical use have also been confirmed by a phase 2 clinical study (Joos et al., 2006). In rhesus macaques, passive immunization of 4E10 and $2 \mathrm{~F} 5$ provides protection against intrarectal challenge with SHIV (Hessell et al., 2010) and delays the viral rebound in HIV-1 infected patients (Mehandru et al., 2007). Although promising, the phospholipid binding property of $2 \mathrm{~F} 5$ and 4E10 compels a more strict safety concern on this autoreactivity issue in future clinical trials (Scherer et al., 2007; Vcelar et al., 2007).

$2 \mathrm{G} 12$ is a human IgG1 cross-clade anti-HIV-1 Nab isolated from the blood of HIV-infected individuals but with a higher neutralization efficacy against B-clade isolates (Buchacher et al., 1994). It recognizes an $\mathrm{N}$-linked high-mannose glycan cluster on the surface of gp120 with its unique dimeric structure (Trkola et al., 1996). 2G12 can form natural dimers that involve a domain swap between two adjacent heavy chains with multivalent binding interface that facilitates binding to its carbohydrates epitope on gp120 (Calarese et al., 2003). Compared to $2 \mathrm{G} 12$ monomer, dimeric $2 \mathrm{G} 12$ shows a significant increase in neutralization potency by both in vitro and in vivo assays without selecting for complete HIV-1 escape mutants (West et al., 2009; Luo et al., 2010). A study shows that $2 \mathrm{G} 12$ can effectively protect against SHIV challenge in macaque models even at a low serum concentration (Hessell et al., 2009). Moreover, combining with $4 \mathrm{E} 10$ and $2 \mathrm{~F} 5,2 \mathrm{G} 12$ shows a protective ability to suppress HIV-1 replication in humans despite the selected viral escape mutants (Baba et al., 2000; Trkola et al., 2005), partially due to its long in vivo half-life (Joos et al., 2006).

Ibalizumab (5A8, TNX-355, TMB-355) is a humanized monoclonal Nab that targets the domain 2 of the CD4 receptor (Moore et al., 1992). A detailed epitope mapping study suggests that some residues within domain 1 also contribute to the binding (Song et al., 2010). Ibalizumab serves as a molecular lock on CD4, which does not interfere with the binding of virion, but it does abort its capability of inducing conformational changes in gp120 through a noncompetitive inhibition manner. After Ibalizumab binding, gp120 is locked into an unfit state for co-receptor interaction (Burkly et al., 1992; Moore et al., 1992). Ibalizumab and T-20 exhibit a synergistic antiviral activity in vitro (Zhang et al., 2006). However, passive immunization of Ibalizumab resulted in a transient suppression of SIV replication in macaques, together with anti-lbalizumab response and resistant viral mutants detected (Reimann et al., 2002). In clinical phase $1 \mathrm{~b}$ study, HIV-1 infected patients were intravenously injected with Ibalizumab. Twenty out of 22 patients had a significant reduction in plasma viral load along with resistant viruses retaining CD4 dependency identified (Jacobson et al., 2009). A further phase 2a study in treatment-experienced subjects indicated that Ibalizumab with an optimized background regimen further reduced plasma viremia compared to a background regimen at week 24 (Norris et al., 2006), leading to a phase $2 b$ dose optimization study under investigation.

PRO-140 (PA14) is a humanized murine anti-CCR5 monoclonal antibody with potent neutralizing activity against HIV-1 of subtypes A, B, C, E, F at low nanomolar concentrations without preventing chemokine-stimulated CCR5 signaling (Olson et al., 1999; Trkola et al., 2001). Alanine scanning indicated that $\mathrm{PRO}-140$ recognizes a conformational epitope spanning the $\mathrm{N}$-terminus, extracellular loops 1 and 2 on CCR5. When used in combination with Maraviroc, Vicriviroc and TAK-779, synergistic drug effect was observed as compared to additive effects when combined with reverse transcriptase inhibitors (Murga et al., 2006). In a phase 1b study, a substantially enhanced mean reduction of viral load was observed in $2 \mathrm{mg} / \mathrm{kg}$ and $5 \mathrm{mg} / \mathrm{kg}$ groups of PRO-140 as compared with the placebo control. A phase 2a study showed similar results, in which the reduction was durable for 2-3 weeks after PRO-140 administration provided a promise for single dose weekly therapy (Jacobson et al., 2010a). Moreover, weekly or biweekly subcutaneous administration of $\mathrm{PRO}-140$ resulted in significantly enhanced mean reduction in HIV-1 load in another phase 2a clinical trial (Jacobson et al., 2010b). These findings revealed a potent and long-lasting antiviral activity of PRO-140 in vivo.

VRC01-like Nabs, including VRC01-03 and VRCPG04, 
are a new class of human anti-HIV-1 monoclonal Nabs that specifically target CD4-binding site of gp120 with extraordinary neutralization potency and breadth (Wu et al., 2010, 2011). These Nabs were directly cloned from antigen-specific $B$ cells of a HIV-1 infected individual selected with potent neutralization sera. VRC01, a representative of these Nabs, can neutralize over $90 \%$ of circulating HIV-1 isolates tested in vitro. The crystal structure of VRC01 in complex with gp120 shows that by partial mimicry of the CD4 receptor, VRC01 directly contacts with gp120 in the CD4-binding site, where defined as a site of vulnerability for antibody access (Zhou et al., 2010). Further studies by deep sequencing and crystal structure reveal that VRC01-like Nabs share a similar mode of gp120 recognition though harboring diverged sequences, indicating a common pathway of B cell affinity maturation that highly contributes to the broad neutralization capacity (Scheid et al., 2011; Wu et al., 2011). As a preliminary study suggests that VRC01 does not have significant reactivity with human antigens, this antibody, therefore, has great potential for in vivo application of passive immunization. To this end, humanized mice are completely protected from HIV-1 infection after vectored-passive immunization of b12 and VRC01 (Balazs et al., 2012).

PG9 and PG16 are two somatically related human Nabs that can neutralize $70 \%-80 \%$ of globally circulating HIV-1 isolates. They were isolated from a HIV-1 (clade A) infected donor, who presents broad and potent neutralizing serum activity as determined by a high-throughput functional assay (Walker et al., 2009). As compared to b12 and 2G12, PG9 and PG16 exhibit enhanced neutralizing ability against non-clade $B$ viruses, and they have a preference to recognize assembled spike viral rather than monomeric gp120, suggesting potential new epitopes for immunogen design. Both of them contain a long protruding CDR H3 loop penetrating a $\mathrm{N}$-linked glycan shield to variable regions of gp120 (Pancera et al., 2010; McLellan et al., 2011). This so-called "hammerhead" subdomain is a common structure shared by antibodies that target the highly glycosylated V1V2 region of gp120, and is responsible for the neutralization and binding specificity of these antibodies.

Using the same technique of PG9 and PG16, another new class of PGT human monoclonal Nabs was isolated (Walker et al., 2011). Some PGT Nabs have a potency of 10 -fold more than PG9, PG16 and VRC01 bnAbs. At concentrations less than $0.1 \mu \mathrm{g} / \mathrm{mL}$, PGT Nabs are able to neutralize $27 \%$ to $50 \%$ of viruses tested. They, therefore, could possibly provide protection at relatively low serum concentrations. PGT128, the broadest Nab among this class, interacts with a conserved site of V3 and two glycans of the gp120 subunit, which determines its high binding affinity and wide-ranging specificity (Pejchal et al., 2011). In addition, a recent study reports another HIV-1 gp41 MPER-specific antibody, named 10E8, which neutralizes $98 \%$ of viruses tested (Huang et al., 2012). In contrast to $2 \mathrm{~F} 5$ and 4E10, 10E8 does not bind phospholipids, is not autoreactive, and binds cell-surface envelope. The structure of 10E8 in complex with the complete MPER reveals a vulnerable site consisted of a narrow stretch of highly conserved gp41-hydrophobic residues and a critical arginine or lysine just before the transmembrane region. These residues are critical for neutralization by testing resistant HIV-1 variants. It, however, remains elusive whether or not HIV-1 vaccines could induce similar bnAbs to this region.

\section{SYNTHESIZED PEPTIDES AND POLYMERS}

Recombinant antibody-like peptides, synthesized polymers, modified chemokines and structural mimic oligomers belong to this class of entry inhibitors (Fig. 1). They inhibit HIV-1 infectivity by distinct mechanisms, but they usually have high potency in common. In this class, the first FDA-approved clinical drug targeting HIV-1 entry, T-20, and other drugs in pipeline are described as follows.

PR0-542 (CD4-lgG2) is a recombinant antibody-like heterotetramer. It mimics the CD4 receptor and competitively binds to the CD4-binding sites on gp120. PRO-542 exerts potent neutralizing activity against the cell-free HIV-1 infection and cell-to-cell virus transmission in vitro (Allaway et al., 1995). It also protects hu-PBL-SCID mice from HIV-1 challenge (Gauduin et al., 1998). Co-administration of PRO-542 and T-20 contribute to synergistic inhibition against diverse HIV-1 subtypes (Nagashima et al., 2001). Clinical phase $1 / 2$ studies reveal that PRO-542 is well tolerated by both HIV-1 infected adults and children, and confers sustained reduction in HIV-1 load (Shearer et al., 2000; Jacobson et al., 2004). These findings support the development of PRO-542 as an approved medication for clinical use.

PR0-2000, a naphthalene sulfonate polymer, blocks both CCR5- and CXCR4-tropic HIV-1 infection (Fig. 2A). It binds to the CD4 molecule and competitively inhibits binding of gp120 (Rusconi et al., 1996). It may also bind to CXCR4 and gp120, suggesting multiple mechanisms of inhibition (Huskens et al., 2009). In a formulation of microbicide, it protects human female genital tissues against HIV-1 infection (Greenhead et al., 2000). It also inhibits DC-mediated virus transfer in vitro (Teleshova et al., 2008). Phase 1 trials of PRO-2000 microbicide gel have revealed its safety and acceptability in healthy women (Smita et al., 2006). PRO-2000 microbicide gel is also well tolerated by HIV-infected women and men (Mayer et al., 2003; Tabet et al., 2003). Unfortunately, PRO-2000 gel showed only modest protection among women against HIV-1 in a phase 2/2b study (Abdool Karim et al., 2011). In a phase 3 randomized clinical trial, HIV-1 negative and sexually active women were randomly assigned into two groups, applying PRO-2000 microbicide gel or placebo gel, respectively, within an hour before sexual activity. HIV-1 incidence was comparable between the two groups. PR0-2000 microbicide gel, therefore, failed to show effectiveness as a woman-controlled prevention method against HIV-1 transmission (McCormack et al., 2010). 


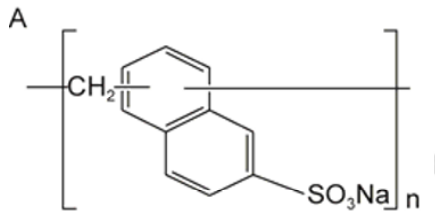

PRO-2000
(4-68)

RANTES



PSC-RANTES

D

\begin{tabular}{|c|c|c|c|c|}
\hline \multicolumn{5}{|c|}{ Sifuvirtide - T-20 -} \\
\hline FP & HR1 & HR2 & TM & \\
\hline
\end{tabular}

T-20

YTSLIHSLIEESQNQQEKNEQELLELDKWASLWNWF

Sifuvirtide SWETWEREIENYTRQIYRILEESQEQQDRNERDLLE

E<smiles>COc1cncc2[nH]cc(C(=O)C(=O)N3CCN(C(=O)c4ccccc4)C[C@H]3C)c12</smiles>

$\mathrm{F}$<smiles>[R]n1cc(C(=O)C(=O)N2CCN(C(=O)c3ccccc3)CC2)c2c(OC)cnc(OC)c21</smiles>

Figure 2. Structures or sequences of synthesized polymers, peptides and small molecules. (A) PRO-2000. (B) RANTES. (C) PSC-RANTES. (D) T-20 and Sifuvirtide as depicted in the schematic representation of HIV-1 ${ }_{\mathrm{HXB} 2}$ gp41 (FP: Fusion peptide; NHR: Heptad repeat 1; CHR: Heptad repeat 2; TM: Transmembrane domain). (E) BMS-378806. (F) BMS-488043.

RANTES, a $\beta$-chemokine ligand, was found to inhibit HIV-1 infection in lymphocytes, which led to the identification of CCR5 as one of the co-receptors for HIV-1 entry (Fig. 2B) (Deng et al., 1996). Biologically, RANTES can activate CCR5 signaling pathways that may promote inflammatory effects. To remove these effects, chemical modification of $\mathrm{N}$-terminus result in met-RANTES (Proudfoot et al., 1996), AOPRANTES (Simmons et al., 1997), NNY-RANTES (Mosier et al., 1999) and PSC-RANTES (Fig. 2C) (Pastore et al., 2003). These RANTES derivatives inhibit HIV-1 infection by inducing CCR5 internalization besides blocking virion binding. PSC-RANTES, in the formulation of microbicide, provides potent protection against SHIV transmission in rhesus macaques (Lederman et al., 2004). Some mutant viruses have been identified but whether they are resistant to PSC-RANTES remains controversial (Dudley et al., 2009; Nedellec et al., 2010).

T-20 (DP-178, Fuzeon, Enfuvirtide) is a FDA approved medication targeting the fusion step of HIV-1 entry (Fig. 2D). It is a synthetic peptide that consists of 36 amino acids spanning the heptad repeat (HR) 2 region of gp41 (Wild et al., 1993). T-20 directly binds to the central coiled-coil HR1 region and completely inhibits the native HR1-HR2 interaction and the sequential formation of the six-helix bundle structure, a necessary process in membrane fusion (Chen et al., 1995). It inhibits potently both CCR5-tropic and CXCR4-tropic HIV-1 but not HIV-2 and SIV due to sequence variations (Reeves et al., 2002; Witvrouw et al., 2004). Clinical T-20 escape viruses result from emergence of mutations in the target sequence on gp41 (Wei et al., 2002), but are still susceptible to other entry inhibitors such as Vicriviroc and AMD3100 (Ray et al., 2007), consistent with a synergistic effect between T-20 and AMD3100 in vitro (Tremblay et al., 2000). Two phase 3 studies, TORO1 and TORO2, showed that at week 24 the T-20 groups exhibit lower mean viral load, greater percentage of patients with less than $50 \mathrm{HIV}-1$ RNA copies $/ \mathrm{mL}$, greater increase in $\mathrm{CD}^{+}$cell count and fewer subjects encountering virologic failure as compared with the optimized background regimen alone group (Lalezari et al., 2003; Lazzarin et al., 2003). Moreover, data collected at week 48 further confirm the safety and efficacy of T-20 in treatment-experienced patients (Nelson et al., 2005; Trottier et al., 2005). T-20 has successfully been included into other optimized background regimens containing Tipranavir (Cahn et al., 2006; Hicks et al., 2006), Darunavir (Clotet et al., 2007; Katlama et al., 2007), Raltegravir (Grinsztejn et al., 2007) and Etravirine (Lazzarin et al., 2007; Madruga et al., 2007). Although T-20 is the first HIV entry inhibitor for the treatment of AIDS patients, its preventive use is limited due to its relatively low potency, short half-life inconvenient administration, and rapid induction of drug-resistant virus. T-20 is now mainly provided as a second-line medication for patients with drug resistance to reverse transcriptase inhibitors and protease inhibitors. 
As one of the new generation of HIV fusion inhibitors, Sifuvirtide is another mimicking peptide of gp41 but contains a pocket-binding domain (PBD) (Fig. 2D), which is similar to other new fusion inhibitors such as T-1249, T-1144 and CP32M (Eron et al., 2004; He et al., 2008). Sifuvirtide was designed based on its three-dimensional structure that shares some conformational features with native gp41, resulting in higher binding affinity and potency to block HIV entry ( $\mathrm{He}$ et al., 2008). Sifuvirtide can inhibit both CCR5- and CXCR4-tropic HIV-1 infectivity synergistically with T-20. Moreover, T-20 resistant virus retains susceptibility to Sifuvirtide. These observations collectively indicate that these new HIV entry inhibitors have distinct mechanisms of action. Moreover, their combined use with T-20 may improve antiviral potency, pharmacokinetic properties and resistant profiles (Pan et al., 2009). Clinical phase 1a trials demonstrated that by injection Sifuvirtide is safe and well tolerated in healthy volunteers with potential for further development (He et al., 2008).

\section{SMALL MOLECULE ENTRY INHIBITORS}

In comparison to synthetic peptides, small molecule inhibitors are easier for chemical modification to improve antiviral activity while to reduce toxicity. Another major advantage is that this class of drug is often safe, well tolerated and often orally bio-available. The currently developed small molecule entry inhibitors against HIV-1 are discussed below.

BMS-378806 (Fig. 2E) and BMS-488043 (Fig. 2F) inhibit HIV-1 infection by binding gp120, the so-called HIV-1 attachment inhibitors (Lin et al., 2003; Wang et al., 2003; Ho et al., 2006). They function by entering into the CD4 binding pocket of gp120, inducing conformational changes and blocking the interaction between gp120 and CD4 (Guo et al., 2003; Ho et al., 2006). Other studies, however, suggested that these compounds may rather block CD4-induced exposure of gp41 N-terminal heptad repeat (NHR) without affecting CD4 binding or co-receptor binding (Si et al., 2004). In contrast, two new small molecule CD4 mimics, namely NBD-556 and NBD-557, which indeed bind to the Phe43 pocket of gp120, have been identified (Madani et al., 2008). They compete with CD4, induce conformational changes in gp120 and enhance co-receptor binding. As for preventive purpose, the combination of BMS-378806 with CCR5 inhibitor and fusion inhibitor in the formulation of microbicide conferred complete protection against vaginal SHIV challenge in rhesus macaques (Veazey et al., 2005). As compared with BMS-378806, BMS-488043 showed enhanced oral bioavailability and metabolic stability (Wang et al., 2009). Moreover, as revealed in a clinical phase 1 trial in healthy volunteers, BMS-488043 is safe and well tolerated (Hanna et al., 2011). In an 8-day monotherapy conducted in HIV-infected patients, greater mean reduction of viral load was achieved in the BMS-488043-treated group compared to that of the placebo-treated group (Hanna et al., 2011). Resistant viruses with an amino acid substitution near the CD4 binding pocket were detected in subjects from the BMS-488043-treated group (Zhou et al., 2011).

AMD3100 (JM3100, SID791) is a CXCR4-specific small molecule antagonist with potent anti-CXCR4 tropic HIV-1 activity (Fig. 3A) (De Clercq et al., 1994; Donzella et al., 1998). It interacts directly with CXCR4 and inhibits SDF-1a induced signaling. It has little oral bioavailability due to the highly charged nature of its bicyclam structure. In vitro selection resulted in AMD3100-resistant virus with variations in V3 loop (De Vreese et al., 1996). In clinical trials, AMD3100 induced abnormal thrombocytopenia or premature ventricular contraction in 3 of 40 HIV-infected patients (Hendrix et al., 2004). AMD3100 has been discontinued for the development of antiviral therapy but it was approved as a medication in hematopoietic stem cell mobilization with a commercial name of Mozobil/Plerixafor (DiPersio et al., 2009).

TAK-779 is the first non-peptide CCR5 antagonist reported with highly potent and specific inhibitory effect against CCR5-tropic HIV-1 infection (Fig. 3B). It inhibits chemokine binding to CCR5 at nanomolar concentrations (Baba et al., 1999). Mutagenesis analysis showed that its binding pocket is located within the transmembrane domains (TM) 1, 2, 3 and 7 of CCR5. After TAK-779 binding, CCR5 undergoes a conformational change to become resistant to virus entry (Dragic et al., 2000). In clinical trials, TAK-779 induces local irritation at injection sites, which prevents this small molecule inhibitor from further development. The quaternary ammonium moiety of TAK-779 prohibits its oral bioavailability. Subsequent modification led to the discoveries of TAK-652 (Fig. 3C) (Seto et al., 2006) and TAK-220 (Fig. 3D) (Takashima et al., 2005; Imamura et al., 2006), of which both are orally available as subnanomolar anti-HIV-1 inhibitors. TAK-652 resistant virus emerged through in vitro selection shows cross-resistance to TAK-779 but remains sensitive to TAK-220 (Baba et al., 2007). The safety and long half-life of TAK-652 are shown in healthy volunteers (Palleja et al., 2009). TAK-652 also conferred a substantial reduction in viral load in HIV-infected and treatment-experienced patients in a phase 2 clinical study (Lalezari et al., 2011). TAK-220 inhibited diverse subtypes of CCR5-tropic HIV-1 isolated in vitro (Takashima et al., 2005). Synergy was observed between TAK-220 and other classes of antiviral medications at high inhibitory concentrations $\left(\mathrm{IC}_{90}\right.$ and $\left.\mathrm{IC}_{95}\right)$. Currently, the efficacy and safety of TAK-220 are being investigated in clinical trials (Tremblay et al., 2005).

Maraviroc (UK-427857) is the first US FDA-approved CCR5 antagonist currently used in HAART treatment-experienced patients (Fig. 3E) (Dorr et al., 2005). The IC $_{50}$ value of this drug is at low nanomolar levels against primary CCR5-tropic HIV-1 isolates from various subtypes. Maraviroc inhibits chemokine (MIP-1 $\alpha$, MIP- $1 \beta$ and RANTES) binding to CCR5 in addition to inhibiting chemokine-stimulated signaling without inducing CCR5 internalization (Dorr et al., 2005). Maraviroc shows no antagonism with other clinically used 
<smiles>c1cc(CN2CCCNCCNCCCNCC2)ccc1CN1CCCNCCNCCCNCC1</smiles>

AMD3100

B<smiles>Cc1ccc(-c2ccc3c(c2)C=C(C(=O)Nc2ccc(CN(C)C4CCOCC4)cc2)CCC3)cc1</smiles><smiles>CCNCC(C)C</smiles>

E<smiles>Cc1nnc(C(C)C)n1C1CC2CCC(C1)N2CC[C@H](NC(=O)C1CCC(F)(F)CC1)c1ccccc1</smiles>

F<smiles>COC[C@@H](c1ccc(C(F)(F)F)cc1)N1CCN(C2(C)CCN(C(=O)c3c(C)ncnc3C)CC2)C[C@@H]1C</smiles><smiles>CCCCN1C(=O)[C@H]([C@H](O)C2CCCCC2)NC(=O)C12CCN(Cc1ccc(OC3=CC=C(C(=O)O)CC3)cc1)CC2</smiles>

$\mathrm{H}$

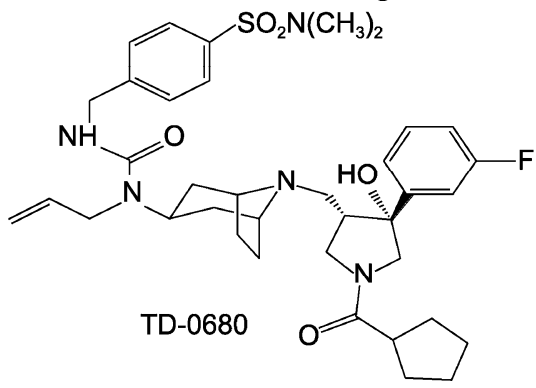

Figure 3. Structures of small molecule inhibitors. CXCR4 inhibitor: (A) AMD3100. CCR5 inhibitors: (B) TAK-779, (C) TAK-652, (D)

TAK-220, (E) Maraviroc, (F) Vicriviroc, (G) Aplaviroc and (H) TD-0680.

antiviral agents, such as transcriptase inhibitor, protease inhibitor and fusion inhibitor (Dorr et al., 2005). The critical amino acids on CCR5 involved in the interaction with Maraviroc are located within the transmembrane domains (Kondru et al., 2008). Maraviroc drug-resistant variants are selected from some primary viral isolates in vitro, resulting from either a tropism shift to CXCR4 or an adaptation to utilize Maraviroc-bound CCR5 (Westby et al., 2007). Amino acid substitutions in V3 loop contributed to both of the two types of resistances (Westby et al., 2007). In phase 3 clinical trials (MOTIVATE $1 \& 2$ ), randomly assigned patients, who had exclusively CCR5-tropic HIV-1, received $300 \mathrm{mg}$ Maraviroc once or twice daily or placebo, together with an optimized background regimen. In combined analysis, the mean reduction of viral load at week 48 was 0.9 - and 1.05- log10 cop$\mathrm{ies} / \mathrm{mL}$ greater in Maraviroc once and twice daily groups, respectively, than that in placebo group, together with higher frequencies of patients whose viral load had been suppressed to less than 50 copies $/ \mathrm{mL}$ and of $\mathrm{CD}^{+}$count increase (Fatkenheuer et al., 2008; Gulick et al., 2008). In an- other phase 3 clinical trial (MERIT), treatment-naïve patients were recruited and the efficacy and safey of Maraviroc as a first-line regimen were investigated. At week 48, a similar proportion of patients with less than 50 copies HIV RNA/mL was achieved in the Maraviroc-treated group, as compare with that in the Efavirenz group (a reverse transcriptase inhibitor), but $\mathrm{CD}^{+}$cell count rebound was greater in patients received Maraviroc (Cooper et al., 2010). These observations were confirmed by week 96 analysis (Hardy et al., 2010; Sierra-Madero et al., 2010). The emergence of pre-existing CXCR4-tropic HIV-1 that failed to be detected in pre-treatment screening was related to virologic failure (Fatkenheuer et al., 2008; Cooper et al., 2010). CCR5-tropic Maraviroc-resistant strains have also been reported (Fatkenheuer et al., 2008), and the in vivo acquisition of Maraviroc-resistance was also a result of V3 sequence changes, similar to that from in vitro selection (Tilton et al., 2010). Maraviroc-based microbicide gel is now under preclinical investigation.

Vicriviroc (SCH-417690, SCH-D) is a potent, orally avail- 
able, pyrimidine-derived CCR5 specific inhibitor (Fig. 3F) (Strizki et al., 2005). It has broad-spectrum inhibitory activity against diverse lab-adapted or clinically-isolated CCR5-tropic HIV-1 strains at sub-nanomolar concentrations. Like Maraviroc, Vicriviroc also blocks chemokine binding to CCR5 and subsequent signaling. Synergistic effect was observed when Vicriviroc was combined with other antiviral drugs (Strizki et al., 2005). Escape variants under the selection pressure of vicriviroc did not switch to CXCR4 tropism but evolved mutations in fusion peptide region of gp41 (Marozsan et al., 2005; Berro et al., 2009). In a phase 2 clinical trial (VICTOR-E), randomized treatment-experienced subjects receiving $20 \mathrm{mg}$ of Vicriviroc once daily had a significantly greater mean reduction in viral load from the baseline as well as a significantly better recovery of mean $\mathrm{CD}^{+}$cell count than those receiving placebo at week 48 (Suleiman et al., 2010). Another phase 2 trial (ACTG A5211) piloted in treatment-experienced patients showed that during a period of 24 weeks, fewer subjects from the Vicriviroc arms experienced virologic failure than those from the placebo arm (Crawford et al., 2010). This result was further supported by a 48 weeks follow-up study. Up to 3 years, $49 \%$ of patients achieving a viral load of less than 50 copies/mL within 24 weeks did not encounter viral rebound (Wilkin et al., 2010). Unexpectedly, two phase 3 studies (VICTOR-E3 and E4) did not reach statistically significant difference in protective efficacy between the Vicriviroc and placebo groups, forcing the discontinuation to seek for FDA's approval (Gathe et al., 2010).

Aplaviroc (GW873140, ONO4128, AK602) is another noncompetitive, CCR5 specific antagonist (Fig. 3G). It exhibits potent antiviral activity at subnanomolar $\mathrm{EC}_{50}$ against diverse CCR5 tropic HIV-1 (Maeda et al., 2004). It inhibits the recognition of MIP-1 $\alpha$ but not of MIP-1 $\beta$ and RANTES. Chemokine-induced CCR5 signaling is also blocked by Aplaviroc (Maeda et al., 2004). Co-administration of Aplaviroc with other CCR5 allosteric inhibitors in blocking MIP-1a binding showed an antagonistic effect, indicating that they may share a common site of action on CCR5 (Watson et al., 2005). Synergistic anti-HIV-1 activity was observed in the combination of Aplaviroc with reverse transcriptase inhibitors and T-20 (Nakata et al., 2008). In a short-term monotherapy for HIV-1 infected patients, Aplaviroc was well tolerated and provided a robust reduction of viremia (Lalezari et al., 2005). However, phase $2 \mathrm{~b} / 3$ clinical trials (ASCENT and EPIC) were halted due to the severe hepatotoxicity in some subjects (Nichols et al., 2008).

TD-0680 is a recently discovered CCR5 antagonist (Fig. $3 \mathrm{H})$. It displays the greatest potency against a diverse group of R5-tropic HIV-1 and SIV strains when compared to its prodrug TD-0232, the FDA-approved CCR5 antagonist Maraviroc, and TAK-779 with $\mathrm{EC}_{50}$ values in the subnanomolar range $(0.09-2.29 \mathrm{nmol} / \mathrm{L}$ ) (Kang et al., 2012). It is equally potent at blocking envelope-mediated cell-to-cell fusion, cell-mediated viral transmission, as well as the replication of a TAK-779/Maraviroc-resistant HIV-1 variant. This drug may offer an advantage over a potent CD4bs directed neutralizing antibody that was inefficient to block cell-mediated viral transmission (Abela et al., 2012). Interestingly, TD-0232 and TD-0680 function differently despite binding to a similar transmembrane (TM) pocket of CCR5. Site-directed mutagenesis, drug combination and antibody blocking assays have revealed a novel mechanism of action of TD-0680. Besides binding to the TM pocket, the unique exo-configuration of TD-0680 protrudes and sterically blocks access to the ECL-2 region of CCR5, thereby interrupting the interaction between virus and its co-receptor more effectively (Kang et al., 2012). TD-0680, therefore, merits development as an anti-HIV-1 agent for therapeutic purposes or as a topical microbicide for the prevention of sexual transmission of R5-tropic HIV-1. In addition, since TD-0680 also blocks rhesus CCR5 effectively, it makes it possible to be tested in macaque models for efficacy evaluation (Chen et al., 1997; Kang et al., 2012).

\section{GENE THERAPIES}

With the rapid progress of gene engineering, targeted gene manipulation technology has become more and more attractive for illness treatment, including HIV-1 infection. This trend is boosted by developed applications of restriction endoclease, RNA inference (RNAi) and induced pluripotent stem cell (iPSC). Despite of the safety and ethical issues, gene therapy remains a promising targeted intervention method against HIV-1 transmission.

Zinc-finger nuclease (ZFN) is an engineered restriction endonuclease comprising a zinc-finger protein DNA-binding domain and a DNA-cleavage domain (Urnov et al., 2005). The specific disruption of the genomic sequence around a target site is determined by the specific assembly of zinc-finger motifs in the DNA-binding domain. The significance of genome editing by ZFN is that its transient expression can result in permanent gene disruption (Urnov et al., 2005). The fact that individuals with homozygous CCR5 $\Delta 32$ and red-capped mangabeys with homozygous CCR5 $\triangle 24$ deletions are apparently normal but protected against CCR5-tropic viral infections makes CCR5 a preferential target for gene depletion (Liu et al., 1996; Chen et al., 1998). Recently, CCR5-specific ZFNs disrupt endogenous CCR5 in primary $\mathrm{CD}^{+} \mathrm{T}$ cells, providing a robust and stable protection against HIV-1 infection both in vitro and in vivo (Perez et al., 2008). The ZFN-treated $\mathrm{CD}^{+}{ }^{+} \mathrm{T}$ cells can be enriched after CCR5-tropic HIV-1 infection and remain susceptible to CXCR4-tropic virus. Critically, mice engrafted with CCR5 ZFN-treated human $\mathrm{CD}^{+} \mathrm{T}$ cell have a significantly lower viral load post HIV-1 infection, further suggesting its efficacy (Perez et al., 2008). A phase 1 clinical study of this gene therapy conducted in HIV-infected patients showed a rebound of $\mathrm{CD}^{+} \mathrm{T}$ cell count in 5 of 6 subjects (Tebas et al., 2011). CCR5-specific ZFN also induces disruption of CCR5 in $\mathrm{CD}_{3}{ }^{+}$human hematopoietic stem/progenitor cells 
(HSPCs) (Holt et al., 2010). The ZFN-treated CD34 ${ }^{+}$HSPCs preserve the capability of multi-lineage engraftment. Mice transplanted with CCR5 ZFN-modified HSPCs retain normal human cell profiles in peripheral blood and various tissues, and are able to control viral replication after HIV-1 challenge (Holt et al., 2010). These findings are supported by the long-term viral control of a HIV-infected leukemia patient (Hutter et al., 2009). This patient who received CCR5 homozygous $\Delta 32$ deletion stem-cells from a HLA-matched donor had an undetectable level of viremia up to 20 months post the procedure, suggesting a possible cure of HIV-1 infection (Hutter et al., 2009). In addition, CXCR4-specific ZFN-mediated CXCR4 depletion confers human $\mathrm{CD}^{+} \mathrm{T}$ cell resistance against CXCR4-tropic HIV-1 (Wilen et al., 2011). It is possible that the combination of gene silencing and hematopoietic stem cell (HSC) transplantation may be a promising therapeutic cure for HIV-infected patients. Interestingly, after transduction with $I h x 2$, iPSCs differentiated robustly to HSC-like cells, which retained multi-lineage differentiation ability after being transferred to mouse model (Kitajima et al., 2011). This technique potentially circumvents the severe issues of graft-versus-host disease and immune rejection, which are common complications of allogeneic transplantation. Therefore, manipulation of stem cells viable for ZFN-mediated therapy could be developed.

RNAi has been known as a powerful tool to suppress specific protein expression in a posttranscriptional manner (Mello and Conte, 2004). Co-receptor-specific siRNA leads to cell resistance to HIV-1 in vitro using either conventional lentivirus or non-viral system as delivery vectors (Anderson et al., 2009). CD4-specific siRNA also protects target cells from HIV-1 infection (Martinez et al., 2002). Moreover, in vivo delivery of CCR5-specific siRNA effectively inhibits viral replication in both hu-PBL and humanized HSC mice (Kumar et al., 2008). Transplantation of anti-CCR5 siRNA modified $\mathrm{CD} 4^{+}$HPSCs into humanized mice stably down-regulates CCR5 expression in systemic lymphoid organs and contributes to inhibition against HIV-1 (Shimizu et al., 2010). In a combination gene therapy, siRNA together with chimeric TRIM5a and a TAR decoy, provided target cells with complete protection without inducing any escape viruses, further illustrating its potential therapeutic use (Anderson et al., 2009).

Through a genome-wide screen by siRNA library, some novel targets in protein transport machinery have been identified to be essential for HIV-1 entry (Brass et al., 2008). Rab6 and Vps53 are believed to be essential for the retrograde traffic from endosome to trans-Golgi network (Conibear and Stevens, 2000; Del Nery et al., 2006). Depletion of Rab6 and Vps53 by stably expressed short hairpin RNA (shRNA) results in resistance to HIV-1 at the entry phase without altering surface CD4 and co-receptor expression (Brass et al., 2008). The genomic screening, therefore, may provide us with more alternative targets to block HIV-1 entry.

\section{PERSPECTIVES}

The ultimate solution for HIV-1 prevention relies on the development of an effective vaccine. Since such a vaccine remains elusive after 30 years of efforts, HIV-1 has likely evolved in a way to avoid the generation of timely potent bnAbs so that the persistent and latent infection can be firmly established. Meantime, immunogen design based on isolated viruses has repeatedly failed to elicit potent bnAbs, suggesting that infection per se is not the reason underlying the disappointing vaccination. Understanding how bnAbs are induced in patients during the natural course of infection has, therefore, become one of the priorities in the area of HIV-1 vaccine research. To this end, significant progresses have been made in recent years by identifying several novel potent bnAbs from a small fraction of naturally infected individuals, who developed potent neutralizing sera. On one hand, the structural analysis of these bnAbs in complex with bound HIV-1 antigen may shed light on new vaccine design although this so-called "retro-vaccinololgy" approach has yet resulted in an effective vaccine. On the other hand, using the newly identified bnAbs via passive immunization is likely a practical strategy for HIV-1 prevention, which is one of the key messages of this review. Non-vaccine strategies in targeting viral entry phase should have critical implications for HIV-1 prevention.

Despite the astonishing diversity of HIV-1 and its devious strategy to evade the immune system, about $8 \%-25 \%$ infected individuals do develop bnAbs naturally after 1-3 years of infection. Based on B cell genome and bnAb structural analyses, however, most bnAbs harbor a long CDR H3 region and unusual somatic mutations over the course of bnAb-secreting $B$ cell maturation. Currently, due to the lack of a proper animal model to study human $B$ cell maturation and the induction of long CDR H3 bnAbs, it is possible that using active vaccination to elicit potent bnAbs may take years if not decades to fulfill. In contrast, passive immunization by combining recently discovered bnAbs may achieve theoretically maximal neutralization coverage against an extremely large proportion of HIV-1 isolates at a low but effective concentration. It is, therefore, conceivable that some of passive immunization strategies may benefit human populations before an effective vaccine becomes available. Necessary resources should be made available to support such evidence-based (e.g. demonstrated efficacy in SHIV/macaque models) research and developmental plans, and to promote the discoveries of effective bnAb delivery system and of optimized long-half life bnAbs.

Besides passive immunization using bnAbs, other non-vaccine strategies targeting viral entry should also be explored for HIV-1 prevention. These strategies may include the use of synthesized peptides and polymers, small molecule entry inhibitors and even gene therapies, or their combined application as indicated in this review. Although it is 
hard to predict which strategy may lead to an ultimate clinical success, the successful one must be able to effectively block the acquisition of genetically divergent heterosexually and homosexually transmitted HIV-1 strains.

\section{ACKNOWLEDGEMENTS}

We thank Allen Cheung and Joyce Tse for editorial assistance, Zhiwu Tan for preparing figures. This work was supported by Hong Kong Research Grant Council RGC762209/762811/762712, Hong Kong Research for the Control of Infectious Diseases (RFCID) 12110952 and Hong Kong AIDS Trust Fund MSS183R, by the University Development Fund and LKSFM Matching Fund of the University of Hong Kong to AIDS Institute and by the National Science and Technology Major Project 2012ZX10001-009. The authors declare no conflict of interest.

\section{ABBREVIATIONS}

AIDS, acquired immunodeficiency disease; bnAb, broadly-reactive neutralizing antibodie; CCR5, C-C chemokine receptor type 5; CDR, complementary determining region; CXCR4, C-X-C chemokine receptor type 4; $\mathrm{DC}$, dendritic cell; $\mathrm{EC}_{50}$, half maximal effective concentration; ECL, extracellular loop; Env, envelope protein; gp, glycoprotein; HAART, highly active antiretroviral therapy; HIV-1, human immunodeficiency virus type one; HR, heptad repeat; HSC, hematopoietic stem cell; HSPC, human hematopoietic stem/progenitor cell; hu-PBL, human peripheral blood lymphocyte; $\mathrm{IC}_{50}$, half maximal inhibitory concentration; iPSC, induced pluripotent stem cell; LTNP, long-term nonprogressor; MPER, membrane-proximal external region; MRKAd5, Merck adenovirus serotype 5; PI, protease inhibitor; R5-tropic, CCR5-tropic; RNAi, RNA inference; RTI, reverse transcriptase inhibitor; SCID, severe combined immunodeficiency; SDF-1 $\alpha$, stromal cell-derived factor-1 alpha; SHIV, simian/human immunodeficiency virus; shRNA, short hairpin RNA; siRNA, small interfering RNA; SIV, simian immunodeficiency virus; TAR, trans-activation response element; TM, transmembrane domains; TRIM5 $\alpha$, tripartite motif-containing protein 5 alpha isoform; V3, variable loop 3; ZFN, Zinc-finger nuclease

\section{REFERENCES}

Abdool Karim, S.S., Richardson, B.A., Ramjee, G., Hoffman, I.F., Chirenje, Z.M., Taha, T., Kapina, M., Maslankowski, L., Coletti, A., Profy, A., et al. (2011). Safety and effectiveness of BufferGel and $0.5 \% \mathrm{PRO} 2000 \mathrm{gel}$ for the prevention of HIV infection in women. Aids 25, 957-966.

Abela, I.A., Berlinger, L., Schanz, M., Reynell, L., Gunthard, H.F., Rusert, P., and Trkola, A. (2012). Cell-cell transmission enables HIV-1 to evade inhibition by potent CD4bs directed antibodies. PLoS Pathog 8, e1002634.

Allaway, G.P., Davis-Bruno, K.L., Beaudry, G.A., Garcia, E.B., Wong, E.L., Ryder, A.M., Hasel, K.W., Gauduin, M.C., Koup, R.A., McDougal, J.S., et al. (1995). Expression and characterization of CD4-IgG2, a novel heterotetramer that neutralizes primary HIV type 1 isolates. AIDS Res Hum Retrov 11, 533-539.

Anderson, J.S., Javien, J., Nolta, J.A., and Bauer, G. (2009). Preintegration HIV-1 inhibition by a combination lentiviral vector containing a chimeric TRIM5 alpha protein, a CCR5 shRNA, and a TAR decoy. Mol Ther 17, 2103-2114.

Armbruster, C., Stiegler, G.M., Vcelar, B.A., Jager, W., Michael, N.L., Vetter, N., and Katinger, H.W. (2002). A phase I trial with two human monoclonal antibodies (hMAb 2F5, 2G12) against HIV-1. Aids 16, 227-233.

Baba, M., Miyake, H., Wang, X., Okamoto, M., and Takashima, K. (2007). Isolation and characterization of human immunodeficiency virus type 1 resistant to the small-molecule CCR5 antagonist TAK-652. Antimicrob Agents Chemother 51, 707-715.

Baba, M., Nishimura, O., Kanzaki, N., Okamoto, M., Sawada, H., lizawa, Y., Shiraishi, M., Aramaki, Y., Okonogi, K., Ogawa, Y., et al. (1999). A small-molecule, nonpeptide CCR5 antagonist with highly potent and selective anti-HIV-1 activity. Proc Natl Acad Sci U S A 96, 5698-5703.

Baba, T.W., Liska, V., Hofmann-Lehmann, R., Vlasak, J., Xu, W.D., Ayehunie, S., Cavacini, L.A., Posner, M.R., Katinger, H., Stiegler, G., et al. (2000). Human neutralizing monoclonal antibodies of the IgG1 subtype protect against mucosal simian-human immunodeficiency virus infection. Nat Med 6, 200-206.

Balazs, A.B., Chen, J., Hong, C.M., Rao, D.S., Yang, L., and Baltimore, D. (2012). Antibody-based protection against HIV infection by vectored immunoprophylaxis. Nature 481, 81-84.

Barbas, C.F., 3rd, Bjorling, E., Chiodi, F., Dunlop, N., Cababa, D., Jones, T.M., Zebedee, S.L., Persson, M.A., Nara, P.L., Norrby, E., et al. (1992). Recombinant human Fab fragments neutralize human type 1 immunodeficiency virus in vitro. Proc Natl Acad Sci U S A 89, 9339-9343.

Barre-Sinoussi, F., Chermann, J.C., Rey, F., Nugeyre, M.T., Chamaret, S., Gruest, J., Dauguet, C., Axler-Blin, C., Vezinet-Brun, F., Rouzioux, C., et al. (1983). Isolation of a T-lymphotropic retrovirus from a patient at risk for acquired immune deficiency syndrome (AIDS). Science 220, 868-871.

Berro, R., Sanders, R.W., Lu, M., Klasse, P.J., and Moore, J.P. (2009). Two HIV-1 variants resistant to small molecule CCR5 inhibitors differ in how they use CCR5 for entry. PLoS Pathog 5 , e1000548.

Boden, D., Hurley, A., Zhang, L., Cao, Y., Guo, Y., Jones, E., Tsay, J., Ip, J., Farthing, C., Limoli, K., et al. (1999). HIV-1 drug resistance in newly infected individuals. Jama 282, 1135-1141.

Brass, A.L., Dykxhoorn, D.M., Benita, Y., Yan, N., Engelman, A., Xavier, R.J., Lieberman, J., and Elledge, S.J. (2008). Identification of host proteins required for HIV infection through a functional genomic screen. Science 319, 921-926.

Buchacher, A., Predl, R., Strutzenberger, K., Steinfellner, W., Trkola, A., Purtscher, M., Gruber, G., Tauer, C., Steindl, F., Jungbauer, A., et al. (1994). Generation of human monoclonal antibodies against HIV-1 proteins; electrofusion and Epstein-Barr virus transformation for peripheral blood lymphocyte immortalization. AIDS Res Hum Retrov 10, 359-369.

Buchbinder, S.P., Mehrotra, D.V., Duerr, A., Fitzgerald, D.W., Mogg, R., Li, D., Gilbert, P.B., Lama, J.R., Marmor, M., Del Rio, C., et al. (2008). Efficacy assessment of a cell-mediated immunity HIV-1 vaccine (the Step Study): a double-blind, randomised, placebo-controlled, test-of-concept trial. Lancet 372, 1881-1893.

Burkly, L.C., Olson, D., Shapiro, R., Winkler, G., Rosa, J.J., Thomas, D.W., Williams, C., and Chisholm, P. (1992). Inhibition of HIV 
infection by a novel CD4 domain 2-specific monoclonal antibody. Dissecting the basis for its inhibitory effect on HIV-induced cell fusion. J Immunol 149, 1779-1787.

Burton, D.R., Pyati, J., Koduri, R., Sharp, S.J., Thornton, G.B., Parren, P.W., Sawyer, L.S., Hendry, R.M., Dunlop, N., Nara, P.L., et al. (1994). Efficient neutralization of primary isolates of HIV-1 by a recombinant human monoclonal antibody. Science 266, 1024-1027.

Cahn, P., Villacian, J., Lazzarin, A., Katlama, C., Grinsztejn, B., Arasteh, K., Lopez, P., Clumeck, N., Gerstoft, J., Stavrianeas, N., et al. (2006). Ritonavir-boosted tipranavir demonstrates superior efficacy to ritonavir-boosted protease inhibitors in treatment-experienced HIV-infected patients: 24-week results of the RESIST-2 trial. Clin Infect Dis 43, 1347-1356.

Calarese, D.A., Scanlan, C.N., Zwick, M.B., Deechongkit, S., Mimura, Y., Kunert, R., Zhu, P., Wormald, M.R., Stanfield, R.L., Roux, K.H., et al. (2003). Antibody domain exchange is an immunological solution to carbohydrate cluster recognition. Science 300 , 2065-2071.

Chen, C.H., Matthews, T.J., McDanal, C.B., Bolognesi, D.P., and Greenberg, M.L. (1995). A molecular clasp in the human immunodeficiency virus (HIV) type 1 TM protein determines the anti-HIV activity of gp41 derivatives: implication for viral fusion. J Virol 69, 3771-3777.

Chen, L., Kwon, Y.D., Zhou, T., Wu, X., O'Dell, S., Cavacini, L., Hessell, A.J., Pancera, M., Tang, M., Xu, L., et al. (2009). Structural basis of immune evasion at the site of CD4 attachment on HIV-1 gp120. Science 326, 1123-1127.

Chen, Z., Kwon, D., Jin, Z., Monard, S., Telfer, P., Jones, M.S., Lu, C.Y., Aguilar, R.F., Ho, D.D., and Marx, P.A. (1998). Natural infection of a homozygous delta24 CCR5 red-capped mangabey with an R2b-tropic simian immunodeficiency virus. J Exp Med 188, 2057-2065.

Chen, Z., Zhou, P., Ho, D.D., Landau, N.R., and Marx, P.A. (1997). Genetically divergent strains of simian immunodeficiency virus use CCR5 as a coreceptor for entry. J Virol 71, 2705-2714.

Clotet, B., Bellos, N., Molina, J.M., Cooper, D., Goffard, J.C., Lazzarin, A., Wohrmann, A., Katlama, C., Wilkin, T., Haubrich, R., et al. (2007). Efficacy and safety of darunavir-ritonavir at week 48 in treatment-experienced patients with HIV-1 infection in POWER 1 and 2: a pooled subgroup analysis of data from two randomised trials. Lancet 369, 1169-1178.

Conibear, E., and Stevens, T.H. (2000). Vps52p, Vps53p, and Vps54p form a novel multisubunit complex required for protein sorting at the yeast late Golgi. Mol Biol Cell 11, 305-323.

Conley, A.J., Kessler, J.A., 2nd, Boots, L.J., McKenna, P.M., Schleif, W.A., Emini, E.A., Mark, G.E., 3rd, Katinger, H., Cobb, E.K., Lunceford, S.M., et al. (1996). The consequence of passive administration of an anti-human immunodeficiency virus type 1 neutralizing monoclonal antibody before challenge of chimpanzees with a primary virus isolate. J Virol 70, 6751-6758.

Cooper, D.A., Heera, J., Goodrich, J., Tawadrous, M., Saag, M., Dejesus, E., Clumeck, N., Walmsley, S., Ting, N., Coakley, E., et al. (2010). Maraviroc versus efavirenz, both in combination with zidovudine-lamivudine, for the treatment of antiretroviral-naive subjects with CCR5-tropic HIV-1 infection. J Infect Dis 201, 803-813.
Crawford, K.W., Li, C., Keung, A., Su, Z., Hughes, M.D., Greaves, W., Kuritzkes, D., Gulick, R., and Flexner, C. (2010). Pharmacokinetic/pharmacodynamic modeling of the antiretroviral activity of the CCR5 antagonist Vicriviroc in treatment experienced HIV-infected subjects (ACTG protocol 5211). J Acquir Immune Defic Syndr 53, 598-605.

De Clercq, E., Yamamoto, N., Pauwels, R., Balzarini, J., Witvrouw, M., De Vreese, K., Debyser, Z., Rosenwirth, B., Peichl, P., Datema, R., et al. (1994). Highly potent and selective inhibition of human immunodeficiency virus by the bicyclam derivative JM3100. Antimicrob Agents Ch 38, 668-674.

De Vreese, K., Reymen, D., Griffin, P., Steinkasserer, A., Werner, G., Bridger, G.J., Este, J., James, W., Henson, G.W., Desmyter, J., et al. (1996). The bicyclams, a new class of potent human immunodeficiency virus inhibitors, block viral entry after binding. Antivir Res 29, 209-219.

Del Nery, E., Miserey-Lenkei, S., Falguieres, T., Nizak, C., Johannes, L., Perez, F., and Goud, B. (2006). Rab6A and Rab6A' GTPases play non-overlapping roles in membrane trafficking. Traffic 7 , 394-407.

Deng, H., Liu, R., Ellmeier, W., Choe, S., Unutmaz, D., Burkhart, M., Di Marzio, P., Marmon, S., Sutton, R.E., Hill, C.M., et al. (1996). Identification of a major co-receptor for primary isolates of HIV-1. Nature 381, 661-666.

DiPersio, J.F., Uy, G.L., Yasothan, U., and Kirkpatrick, P. (2009). Plerixafor. Nat Rev Drug Discov 8, 105-106.

Donzella, G.A., Schols, D., Lin, S.W., Este, J.A., Nagashima, K.A., Maddon, P.J., Allaway, G.P., Sakmar, T.P., Henson, G., De Clercq, E., et al. (1998). AMD3100, a small molecule inhibitor of HIV-1 entry via the CXCR4 co-receptor. Nat Med 4, 72-77.

Dorr, P., Westby, M., Dobbs, S., Griffin, P., Irvine, B., Macartney, M., Mori, J., Rickett, G., Smith-Burchnell, C., Napier, C., et al. (2005). Maraviroc (UK-427,857), a potent, orally bioavailable, and selective small-molecule inhibitor of chemokine receptor CCR5 with broad-spectrum anti-human immunodeficiency virus type 1 activity. Antimicrob Agents Ch 49, 4721-4732.

Dragic, T., Trkola, A., Thompson, D.A., Cormier, E.G., Kajumo, F.A., Maxwell, E., Lin, S.W., Ying, W., Smith, S.O., Sakmar, T.P., et al. (2000). A binding pocket for a small molecule inhibitor of HIV-1 entry within the transmembrane helices of CCR5. Proc Natl Acad Sci U S A 97, 5639-5644.

Dudley, D.M., Wentzel, J.L., Lalonde, M.S., Veazey, R.S., and Arts, E.J. (2009). Selection of a simian-human immunodeficiency virus strain resistant to a vaginal microbicide in macaques. J Virol 83, 5067-5076.

Duenas-Decamp, M.J., Peters, P., Burton, D., and Clapham, P.R. (2008). Natural resistance of human immunodeficiency virus type 1 to the CD4bs antibody b12 conferred by a glycan and an arginine residue close to the CD4 binding loop. J Virol 82, 5807-5814.

Eckert, D.M., and Kim, P.S. (2001). Mechanisms of viral membrane fusion and its inhibition. Annu Rev Biochem 70, 777-810.

Eron, J.J., Gulick, R.M., Bartlett, J.A., Merigan, T., Arduino, R., Kilby, J.M., Yangco, B., Diers, A., Drobnes, C., DeMasi, R., et al. (2004). Short-term safety and antiretroviral activity of T-1249, a second-generation fusion inhibitor of HIV. J Infect Dis 189, 1075-1083. 
Fatkenheuer, G., Nelson, M., Lazzarin, A., Konourina, I., Hoepelman, A.I., Lampiris, H., Hirschel, B., Tebas, P., Raffi, F., Trottier, B., et al. (2008). Subgroup analyses of maraviroc in previously treated R5 HIV-1 infection. N Engl J Med 359, 1442-1455.

Frankel, S.S., Steinman, R.M., Michael, N.L., Kim, S.R., Bhardwaj, N., Pope, M., Louder, M.K., Ehrenberg, P.K., Parren, P.W., Burton, D.R., et al. (1998). Neutralizing monoclonal antibodies block human immunodeficiency virus type 1 infection of dendritic cells and transmission to T cells. J Virol 72, 9788-9794.

Gathe, J., Diaz, R., Fatkenheuer, G., Zeinecker, J., Mak, C., Vilchez, R., Greaves, W., Kumar, S., Onyebuchi, C., and Dunkle, L. (2010). Phase 3 trials of vicriviroc in treatment-experienced subjects demonstrate safety but not significantly superior efficacy over potent background regimens alone. In XVII conference on Retroviruses and Opportunistic Infections (San Francisco, CA, USA)

Gauduin, M.C., Allaway, G.P., Olson, W.C., Weir, R., Maddon, P.J., and Koup, R.A. (1998). CD4-immunoglobulin G2 protects Hu-PBL-SCID mice against challenge by primary human immunodeficiency virus type 1 isolates. J Virol 72, 3475-3478.

Gray, E.S., Moore, P.L., Bibollet-Ruche, F., Li, H., Decker, J.M., Meyers, T., Shaw, G.M., and Morris, L. (2008). 4E10-resistant variants in a human immunodeficiency virus type 1 subtype C-infected individual with an anti-membrane-proximal external region-neutralizing antibody response. J Virol 82, 2367-2375.

Greenhead, P., Hayes, P., Watts, P.S., Laing, K.G., Griffin, G.E., and Shattock, R.J. (2000). Parameters of human immunodeficiency virus infection of human cervical tissue and inhibition by vaginal virucides. J Virol 74, 5577-5586.

Grinsztejn, B., Nguyen, B.Y., Katlama, C., Gatell, J.M., Lazzarin, A., Vittecoq, D., Gonzalez, C.J., Chen, J., Harvey, C.M., and Isaacs, R.D. (2007). Safety and efficacy of the HIV-1 integrase inhibitor raltegravir (MK-0518) in treatment-experienced patients with multidrug-resistant virus: a phase II randomised controlled trial. Lancet 369, 1261-1269.

Gulick, R.M., Lalezari, J., Goodrich, J., Clumeck, N., DeJesus, E., Horban, A., Nadler, J., Clotet, B., Karlsson, A., Wohlfeiler, M., et al. (2008). Maraviroc for previously treated patients with R5 HIV-1 infection. N Engl J Med 359, 1429-1441.

Guo, Q., Ho, H.T., Dicker, I., Fan, L., Zhou, N., Friborg, J., Wang, T., McAuliffe, B.V., Wang, H.G., Rose, R.E., et al. (2003). Biochemical and genetic characterizations of a novel human immunodeficiency virus type 1 inhibitor that blocks gp120-CD4 interactions. J Virol 77, 10528-10536.

Hammer, S.M., Katzenstein, D.A., Hughes, M.D., Gundacker, H., Schooley, R.T., Haubrich, R.H., Henry, W.K., Lederman, M.M., Phair, J.P., Niu, M., et al. (1996). A trial comparing nucleoside monotherapy with combination therapy in HIV-infected adults with CD4 cell counts from 200 to 500 per cubic millimeter. AIDS Clinical Trials Group Study 175 Study Team. N Engl J Med 335, 1081-1090.

Hanna, G.J., Lalezari, J., Hellinger, J.A., Wohl, D.A., Nettles, R., Persson, A., Krystal, M., Lin, P., Colonno, R., and Grasela, D.M. (2011). Antiviral activity, pharmacokinetics, and safety of BMS-488043, a novel oral small-molecule HIV-1 attachment inhibitor, in HIV-1-infected subjects. Antimicrob Agents Che 55, 722-728.
Hardy, W.D., Gulick, R.M., Mayer, H., Fatkenheuer, G., Nelson, M., Heera, J., Rajicic, N., and Goodrich, J. (2010). Two-year safety and virologic efficacy of maraviroc in treatment-experienced patients with CCR5-tropic HIV-1 infection: 96-week combined analysis of MOTIVATE 1 and 2. J Acquir Immune Defic Syndr 55, 558-564.

He, Y., Xiao, Y., Song, H., Liang, Q., Ju, D., Chen, X., Lu, H., Jing, W., Jiang, S., and Zhang, L. (2008). Design and evaluation of sifuvirtide, a novel HIV-1 fusion inhibitor. J Biol Chem 283, 11126-11134.

Hendrix, C.W., Collier, A.C., Lederman, M.M., Schols, D., Pollard, R.B., Brown, S., Jackson, J.B., Coombs, R.W., Glesby, M.J., Flexner, C.W., et al. (2004). Safety, pharmacokinetics, and antiviral activity of AMD3100, a selective CXCR4 receptor inhibitor, in HIV-1 infection. J Acquir Immune Defic Syndr 37, 1253-1262.

Hessell, A.J., Rakasz, E.G., Poignard, P., Hangartner, L., Landucci, G., Forthal, D.N., Koff, W.C., Watkins, D.I., and Burton, D.R. (2009). Broadly Neutralizing Human Anti-HIV Antibody 2G12 Is Effective in Protection against Mucosal SHIV Challenge Even at Low Serum Neutralizing Titers. Plos Pathog 5 (5):e 1000433.

Hessell, A.J., Rakasz, E.G., Tehrani, D.M., Huber, M., Weisgrau, K.L., Landucci, G., Forthal, D.N., Koff, W.C., Poignard, P., Watkins, D.I., et al. (2010). Broadly neutralizing monoclonal antibodies $2 \mathrm{~F} 5$ and 4E10 directed against the human immunodeficiency virus type 1 gp41 membrane-proximal external region protect against mucosal challenge by simian-human immunodeficiency virus SHIVBa-L. J Virol 84, 1302-1313.

Hicks, C.B., Cahn, P., Cooper, D.A., Walmsley, S.L., Katlama, C., Clotet, B., Lazzarin, A., Johnson, M.A., Neubacher, D., Mayers, D., et al. (2006). Durable efficacy of tipranavir-ritonavir in combination with an optimised background regimen of antiretroviral drugs for treatment-experienced HIV-1-infected patients at 48 weeks in the Randomized Evaluation of Strategic Intervention in multi-drug reSistant patients with Tipranavir (RESIST) studies: an analysis of combined data from two randomised open-label trials. Lancet 368 , $466-475$.

Ho, H.T., Fan, L., Nowicka-Sans, B., McAuliffe, B., Li, C.B., Yamanaka, G., Zhou, N., Fang, H., Dicker, I., Dalterio, R., et al. (2006). Envelope conformational changes induced by human immunodeficiency virus type 1 attachment inhibitors prevent CD4 binding and downstream entry events. J Virol 80, 4017-4025.

Holt, N., Wang, J., Kim, K., Friedman, G., Wang, X., Taupin, V., Crooks, G.M., Kohn, D.B., Gregory, P.D., Holmes, M.C., et al. (2010). Human hematopoietic stem/progenitor cells modified by zinc-finger nucleases targeted to CCR5 control HIV-1 in vivo. Nat Biotechnol 28, 839-847.

Huang, J., Ofek, G., Laub, L., Louder, M.K., Doria-Rose, N.A., Longo, N.S., Imamichi, H., Bailer, R.T., Chakrabarti, B., Sharma, S.K., et al. (2012). Broad and potent neutralization of HIV-1 by a gp41-specific human antibody. Nature 491, 406-412.

Huskens, D., Vermeire, K., Profy, A.T., and Schols, D. (2009). The candidate sulfonated microbicide, PRO 2000, has potential multiple mechanisms of action against HIV-1. Antiv Res 84, 38-47.

Hutter, G., Nowak, D., Mossner, M., Ganepola, S., Mussig, A., Allers, K., Schneider, T., Hofmann, J., Kucherer, C., Blau, O., et al. (2009). Long-term control of HIV by CCR5 Delta32/Delta32 
stem-cell transplantation. N Engl J Med 360, 692-698.

Imamura, S., Ichikawa, T., Nishikawa, Y., Kanzaki, N., Takashima, K., Niwa, S., lizawa, Y., Baba, M., and Sugihara, Y. (2006). Discovery of a piperidine-4-carboxamide CCR5 antagonist (TAK-220) with highly potent Anti-HIV-1 activity. J Med Chem 49, 2784-2793.

Jacobson, J.M., Israel, R.J., Lowy, I., Ostrow, N.A., Vassilatos, L.S., Barish, M., Tran, D.N., Sullivan, B.M., Ketas, T.J., O'Neill, T.J., et al. (2004). Treatment of advanced human immunodeficiency virus type 1 disease with the viral entry inhibitor PRO 542. Antimicrob Agents Ch 48, 423-429.

Jacobson, J.M., Kuritzkes, D.R., Godofsky, E., DeJesus, E., Larson, J.A., Weinheimer, S.P., and Lewis, S.T. (2009). Safety, pharmacokinetics, and antiretroviral activity of multiple doses of ibalizumab (formerly TNX-355), an anti-CD4 monoclonal antibody, in human immunodeficiency virus type 1-infected adults. Antimicrob Agents Ch 53, 450-457.

Jacobson, J.M., Lalezari, J.P., Thompson, M.A., Fichtenbaum, C.J., Saag, M.S., Zingman, B.S., D'Ambrosio, P., Stambler, N., Rotshteyn, Y., Marozsan, A.J., et al. (2010a). Phase 2a study of the CCR5 monoclonal antibody PRO 140 administered intravenously to HIV-infected adults. Antimicrob Agents Ch 54, 4137-4142.

Jacobson, J.M., Thompson, M.A., Lalezari, J.P., Saag, M.S., Zingman, B.S., D'Ambrosio, P., Stambler, N., Rotshteyn, Y., Marozsan, A.J., Maddon, P.J., et al. (2010b). Anti-HIV-1 activity of weekly or biweekly treatment with subcutaneous PRO 140, a CCR5 monoclonal antibody. J Infect Dis 201, 1481-1487.

Joos, B., Trkola, A., Kuster, H., Aceto, L., Fischer, M., Stiegler, G., Armbruster, C., Vcelar, B., Katinger, H., and Gunthard, H.F. (2006). Long-term multiple-dose pharmacokinetics of human monoclonal antibodies (MAbs) against human immunodeficiency virus type 1 envelope gp120 (MAb 2G12) and gp41 (MAbs 4E10 and 2F5). Antimicrob Agents Ch 50, 1773-1779.

Kang, Y., Wu, Z., Lau, T.C., Lu, X., Liu, L., Cheung, A.K., Tan, Z., Ng, J., Liang, J., Wang, H., et al. (2012). CCR5 antagonist TD-0680 uses a novel mechanism for enhanced potency against HIV-1 entry, cell-mediated infection, and a resistant variant. J Biol Chem 287, 16499-16509.

Katlama, C., Esposito, R., Gatell, J.M., Goffard, J.C., Grinsztejn, B., Pozniak, A., Rockstroh, J., Stoehr, A., Vetter, N., Yeni, P., et al. (2007). Efficacy and safety of TMC114/ritonavir in treatment-experienced HIV patients: 24-week results of POWER 1. Aids 21, 395-402.

Kitajima, K., Minehata, K., Sakimura, K., Nakano, T., and Hara, T. (2011). In vitro generation of HSC-like cells from murine ESCs/iPSCs by enforced expression of LIM-homeobox transcription factor Lhx2. Blood 117, 3748-3758.

Kondru, R., Zhang, J., Ji, C., Mirzadegan, T., Rotstein, D., Sankuratri, S., and Dioszegi, M. (2008). Molecular interactions of CCR5 with major classes of small-molecule anti-HIV CCR5 antagonists. Mol Pharmacol 73, 789-800.

Kumar, P., Ban, H.S., Kim, S.S., Wu, H., Pearson, T., Greiner, D.L., Laouar, A., Yao, J., Haridas, V., Habiro, K., et al. (2008). T cell-specific siRNA delivery suppresses HIV-1 infection in humanized mice. Cell 134, 577-586.

Lalezari, J., Gathe, J., Brinson, C., Thompson, M., Cohen, C., Dejesus, E., Galindez, J., Ernst, J.A., Martin, D.E., and Palleja,
S.M. (2011). Safety, efficacy, and pharmacokinetics of TBR-652, a CCR5/CCR2 antagonist, in HIV-1-infected, treatment-experienced, CCR5 antagonist-naive subjects. J Acquir Immune Defic Syndr 57, 118-125.

Lalezari, J., Thompson, M., Kumar, P., Piliero, P., Davey, R., Patterson, K., Shachoy-Clark, A., Adkison, K., Demarest, J., Lou, Y., et al. (2005). Antiviral activity and safety of 873140 , a novel CCR5 antagonist, during short-term monotherapy in HIV-infected adults. Aids 19, 1443-1448.

Lalezari, J.P., Henry, K., O'Hearn, M., Montaner, J.S., Piliero, P.J., Trottier, B., Walmsley, S., Cohen, C., Kuritzkes, D.R., Eron, J.J., Jr., et al. (2003). Enfuvirtide, an HIV-1 fusion inhibitor, for drug-resistant HIV infection in North and South America. N Engl J Med 348, 2175-2185.

Lazzarin, A., Campbell, T., Clotet, B., Johnson, M., Katlama, C., Moll, A., Towner, W., Trottier, B., Peeters, M., Vingerhoets, J., et al. (2007). Efficacy and safety of TMC125 (etravirine) in treatment-experienced HIV-1-infected patients in DUET-2: 24-week results from a randomised, double-blind, placebo-controlled trial. Lancet 370, 39-48.

Lazzarin, A., Clotet, B., Cooper, D., Reynes, J., Arasteh, K., Nelson, M., Katlama, C., Stellbrink, H.J., Delfraissy, J.F., Lange, J., et al. (2003). Efficacy of enfuvirtide in patients infected with drug-resistant HIV-1 in Europe and Australia. N Engl J Med 348, 2186-2195.

Lederman, M.M., Veazey, R.S., Offord, R., Mosier, D.E., Dufour, J., Mefford, M., Piatak, M., Jr., Lifson, J.D., Salkowitz, J.R., Rodriguez, B., et al. (2004). Prevention of vaginal SHIV transmission in rhesus macaques through inhibition of CCR5. Science 306, 485-487.

Lin, P.F., Blair, W., Wang, T., Spicer, T., Guo, Q., Zhou, N., Gong, Y.F., Wang, H.G., Rose, R., Yamanaka, G., et al. (2003). A small molecule HIV-1 inhibitor that targets the HIV-1 envelope and inhibits CD4 receptor binding. Proc Natl Acad Sci U S A 100, 11013-11018.

Liu, R., Paxton, W.A., Choe, S., Ceradini, D., Martin, S.R., Horuk, R., MacDonald, M.E., Stuhlmann, H., Koup, R.A., and Landau, N.R. (1996). Homozygous defect in HIV-1 coreceptor accounts for resistance of some multiply-exposed individuals to HIV-1 infection. Cell 86, 367-377.

Lu, X., Liu, L., Zhang, X., Lau, T.C., Tsui, S.K., Kang, Y., Zheng, P., Zheng, B., Liu, G., and Chen, Z. (2012). F18, a novel small-molecule nonnucleoside reverse transcriptase inhibitor, inhibits HIV-1 replication using distinct binding motifs as demonstrated by resistance selection and docking analysis. Antimicrob Agents Ch 56, 341-351.

Luo, M., Liu, H., Zhuang, K., Liu, L., Su, B., Yang, R., Tien, P., Zhang, L., Gui, X., and Chen, Z. (2009). Prevalence of drug-resistant HIV-1 in rural areas of Hubei province in the People's Republic of China. J Acquir Immune Defic Syndr 50, 1-8.

Luo, X.M., Lei, M.Y.Y., Feidi, R.A., West, A.P., Balazs, A.B., Bjorkman, P.J., Yang, L.L., and Baltimore, D. (2010). Dimeric 2G12 as a Potent Protection against HIV-1. Plos Pathog 6 (12):e 1001225.

Madani, N., Schon, A., Princiotto, A.M., Lalonde, J.M., Courter, J.R., Soeta, T., Ng, D., Wang, L., Brower, E.T., Xiang, S.H., et al. (2008). Small-molecule CD4 mimics interact with a highly 
conserved pocket on HIV-1 gp120. Structure 16, 1689-1701.

Madruga, J.V., Cahn, P., Grinsztejn, B., Haubrich, R., Lalezari, J., Mills, A., Pialoux, G., Wilkin, T., Peeters, M., Vingerhoets, J., et al. (2007). Efficacy and safety of TMC125 (etravirine) in treatment-experienced HIV-1-infected patients in DUET-1: 24-week results from a randomised, double-blind, placebo-controlled trial. Lancet 370, 29-38.

Maeda, K., Nakata, H., Koh, Y., Miyakawa, T., Ogata, H., Takaoka, Y., Shibayama, S., Sagawa, K., Fukushima, D., Moravek, J., et al. (2004). Spirodiketopiperazine-based CCR5 inhibitor which preserves CC-chemokine/CCR5 interactions and exerts potent activity against R5 human immunodeficiency virus type 1 in vitro. J Virol 78, 8654-8662.

Marozsan, A.J., Kuhmann, S.E., Morgan, T., Herrera, C., Rivera-Troche, E., Xu, S., Baroudy, B.M., Strizki, J., and Moore, J.P. (2005). Generation and properties of a human immunodeficiency virus type 1 isolate resistant to the smal molecule CCR5 inhibitor, SCH-417690 (SCH-D). Virology 338, 182-199.

Martinez, M.A., Gutierrez, A., Armand-Ugon, M., Blanco, J., Parera, M., Gomez, J., Clotet, B., and Este, J.A. (2002). Suppression of chemokine receptor expression by RNA interference allows for inhibition of HIV-1 replication. Aids 16, 2385-2390.

Mayer, K.H., Karim, S.A., Kelly, C., Maslankowski, L., Rees, H., Profy, A.T., Day, J., Welch, J., and Rosenberg, Z. (2003). Safety and tolerability of vaginal PRO 2000 gel in sexually active HIV-uninfected and abstinent HIV-infected women. Aids 17, 321-329.

McCormack, S., Ramjee, G., Kamali, A., Rees, H., Crook, A.M., Gafos, M., Jentsch, U., Pool, R., Chisembele, M., Kapiga, S., et al. (2010). PRO2000 vaginal gel for prevention of HIV-1 infection (Microbicides Development Programme 301): a phase 3, randomised, double-blind, parallel-group trial. Lancet 376 1329-1337.

McLellan, J.S., Pancera, M., Carrico, C., Gorman, J., Julien, J.P., Khayat, R., Louder, R., Pejchal, R., Sastry, M., Dai, K., et al. (2011). Structure of HIV-1 gp120 V1/V2 domain with broadly neutralizing antibody PG9. Nature 480, 336-343.

Mehandru, S., Vcelar, B., Wrin, T., Stiegler, G., Joos, B., Mohri, H., Boden, D., Galovich, J., Tenner-Racz, K., Racz, P., et al. (2007) Adjunctive passive immunotherapy in human immunodeficiency virus type 1-infected individuals treated with antiviral therapy during acute and early infection. J Virol 81, 11016-11031.

Mello, C.C., and Conte, D., Jr. (2004). Revealing the world of RNA interference. Nature 431, 338-342.

Mo, H., Stamatatos, L., Ip, J.E., Barbas, C.F., Parren, P.W., Burton, D.R., Moore, J.P., and Ho, D.D. (1997). Human immunodeficiency virus type 1 mutants that escape neutralization by human monoclonal antibody lgG1b12. off. J Virol 71 6869-6874.

Moore, J.P., Sattentau, Q.J., Klasse, P.J., and Burkly, L.C. (1992). A monoclonal antibody to CD4 domain 2 blocks soluble CD4-induced conformational changes in the envelope glycoproteins of human immunodeficiency virus type 1 (HIV-1) and HIV-1 infection of CD4+ cells. J Virol 66, 4784-4793.

Mosier, D.E., Picchio, G.R., Gulizia, R.J., Sabbe, R., Poignard, P., Picard, L., Offord, R.E., Thompson, D.A., and Wilken, J. (1999).
Highly potent RANTES analogues either prevent CCR5-using human immunodeficiency virus type 1 infection in vivo or rapidly select for CXCR4-using variants. J Virol 73, 3544-3550.

Murga, J.D., Franti, M., Pevear, D.C., Maddon, P.J., and Olson, W.C. (2006). Potent antiviral synergy between monoclonal antibody and small-molecule CCR5 inhibitors of human immunodeficiency virus type 1. Antimicrob Agents Ch 50, 3289-3296.

Muster, T., Steindl, F., Purtscher, M., Trkola, A., Klima, A., Himmler, G., Ruker, F., and Katinger, H. (1993). A conserved neutralizing epitope on gp41 of human immunodeficiency virus type 1. J Virol 67, 6642-6647.

Nagashima, K.A., Thompson, D.A., Rosenfield, S.I., Maddon, P.J., Dragic, T., and Olson, W.C. (2001). Human immunodeficiency virus type 1 entry inhibitors PRO 542 and T-20 are potently synergistic in blocking virus-cell and cell-cell fusion. $\mathrm{J}$ Infect Dis 183, 1121-1125.

Nakamura, K.J., Gach, J.S., Jones, L., Semrau, K., Walter, J., Bibollet-Ruche, F., Decker, J.M., Heath, L., Decker, W.D., Sinkala, M., et al. (2010). 4E10-resistant HIV-1 isolated from four subjects with rare membrane-proximal external region polymorphisms. PLoS One 5, e9786.

Nakata, H., Steinberg, S.M., Koh, Y., Maeda, K., Takaoka, Y., Tamamura, H., Fujii, N., and Mitsuya, H. (2008). Potent synergistic anti-human immunodeficiency virus (HIV) effects using combinations of the CCR5 inhibitor aplaviroc with other anti-HIV drugs. Antimicrob Agents Ch 52, 2111-2119.

Nedellec, R., Coetzer, M., Lederman, M.M., Offord, R.E., Hartley, O., and Mosier, D.E. (2010). "Resistance" to PSC-RANTES revisited: two mutations in human immunodeficiency virus type 1 HIV-1 SF162 or simian-human immunodeficiency virus SHIV SF162-p3 do not confer resistance. J Virol 84, 5842-5845.

Nelson, M., Arasteh, K., Clotet, B., Cooper, D.A., Henry, K., Katlama, C., Lalezari, J.P., Lazzarin, A., Montaner, J.S., O'Hearn, M., et al. (2005). Durable efficacy of enfuvirtide over 48 weeks in heavily treatment-experienced HIV-1-infected patients in the T-20 versus optimized background regimen only 1 and 2 clinical trials. J Acquir Immune Defic Syndr 40, 404-412.

Nichols, W.G., Steel, H.M., Bonny, T., Adkison, K., Curtis, L., Millard, J., Kabeya, K., and Clumeck, N. (2008). Hepatotoxicity observed in clinical trials of aplaviroc (GW873140). Antimicrob Agents Ch $52,858-865$.

Norris, D., Morales, J., Gathe, J., Godofsky, E., Garcia, F., Hardwicke, R., and Lewis, S. (2006). Phase 2 efficacy and safety of the novel entry inhibitor, TNX-355, in combination with optimized background regimen (OBR). In XVI International AIDS Conference (Toronto, ON, Canada).

Olson, W.C., Rabut, G.E., Nagashima, K.A., Tran, D.N., Anselma, D.J., Monard, S.P., Segal, J.P., Thompson, D.A., Kajumo, F., Guo, Y., et al. (1999). Differential inhibition of human immunodeficiency virus type 1 fusion, gp120 binding, and CC-chemokine activity by monoclonal antibodies to CCR5. J Virol 73, 4145-4155.

Palleja, S., Wang-Smith, L., Ogden, R., Martin, D., Driz, R., and Sapirstein, J. (2009). TBR-652, a chemokine receptor 5 (CCR5) antagonist, demonstrates good oral bioavailability and desirable pharmacokinetic (PK) and safety profiles in healthy volunteers. In XXXXVIIII Interscience Conference on Antimicrobial Agents and Chemotherapy (San Francisco, CA, USA). 
Pan, C., Lu, H., Qi, Z., and Jiang, S. (2009). Synergistic efficacy of combination of enfuvirtide and sifuvirtide, the first- and next-generation HIV-fusion inhibitors. Aids 23, 639-641.

Pancera, M., McLellan, J.S., Wu, X., Zhu, J., Changela, A., Schmidt, S.D., Yang, Y., Zhou, T., Phogat, S., Mascola, J.R., et al. (2010). Crystal structure of PG16 and chimeric dissection with somatically related PG9: structure-function analysis of two quaternary-specific antibodies that effectively neutralize HIV-1. J Virol 84, 8098-8110.

Parren, P.W., Marx, P.A., Hessell, A.J., Luckay, A., Harouse, J., Cheng-Mayer, C., Moore, J.P., and Burton, D.R. (2001). Antibody protects macaques against vaginal challenge with a pathogenic R5 simian/human immunodeficiency virus at serum levels giving complete neutralization in vitro. J Virol 75, 8340-8347.

Pastore, C., Picchio, G.R., Galimi, F., Fish, R., Hartley, O., Offord, R.E., and Mosier, D.E. (2003). Two mechanisms for human immunodeficiency virus type 1 inhibition by $\mathrm{N}$-terminal modifications of RANTES. Antimicrob Agents Ch 47, 509-517.

Pejchal, R., Doores, K.J., Walker, L.M., Khayat, R., Huang, P.S., Wang, S.K., Stanfield, R.L., Julien, J.P., Ramos, A., Crispin, M., et al. (2011). A potent and broad neutralizing antibody recognizes and penetrates the HIV glycan shield. Science 334, 1097-1103.

Perez, E.E., Wang, J., Miller, J.C., Jouvenot, Y., Kim, K.A., Liu, O., Wang, N., Lee, G., Bartsevich, V.V., Lee, Y.L., et al. (2008). Establishment of HIV-1 resistance in CD4+ T cells by genome editing using zinc-finger nucleases. Nat Biotechnol 26, 808-816.

Pierson, T.C., and Doms, R.W. (2003). HIV-1 entry and its inhibition. Curr Top Microbiol Immunol 281, 1-27.

Proudfoot, A.E., Power, C.A., Hoogewerf, A.J., Montjovent, M.O., Borlat, F., Offord, R.E., and Wells, T.N. (1996). Extension of recombinant human RANTES by the retention of the initiating methionine produces a potent antagonist. J Biol Chem 271, 2599-2603.

Purtscher, M., Trkola, A., Grassauer, A., Schulz, P.M., Klima, A., Dopper, S., Gruber, G., Buchacher, A., Muster, T., and Katinger, H. (1996). Restricted antigenic variability of the epitope recognized by the neutralizing gp41 antibody 2F5. Aids 10, 587-593.

Purtscher, M., Trkola, A., Gruber, G., Buchacher, A., Predl, R., Steindl, F., Tauer, C., Berger, R., Barrett, N., Jungbauer, A., et al. (1994). A broadly neutralizing human monoclonal antibody against gp41 of human immunodeficiency virus type 1. AIDS Res Hum Retroviruses 10, 1651-1658.

Ray, N., Harrison, J.E., Blackburn, L.A., Martin, J.N., Deeks, S.G., and Doms, R.W. (2007). Clinical resistance to enfuvirtide does not affect susceptibility of human immunodeficiency virus type 1 to other classes of entry inhibitors. J Virol 81, 3240-3250.

Reeves, J.D., Gallo, S.A., Ahmad, N., Miamidian, J.L., Harvey, P.E., Sharron, M., Pohlmann, S., Sfakianos, J.N., Derdeyn, C.A., Blumenthal, R., et al. (2002). Sensitivity of HIV-1 to entry inhibitors correlates with envelope/coreceptor affinity, receptor density, and fusion kinetics. Proc Natl Acad Sci U S A 99, 16249-16254.

Reimann, K.A., Khunkhun, R., Lin, W., Gordon, W., and Fung, M. (2002). A humanized, nondepleting anti-CD4 antibody that blocks virus entry inhibits virus replication in rhesus monkeys chronically infected with simian immunodeficiency virus. AIDS Res Hum Retrov $18,747-755$.
Rerks-Ngarm, S., Pitisuttithum, P., Nitayaphan, S., Kaewkungwal, J., Chiu, J., Paris, R., Premsri, N., Namwat, C., de Souza, M., Adams, E., et al. (2009). Vaccination with ALVAC and AIDSVAX to prevent HIV-1 infection in Thailand. N Engl J Med 361, 2209-2220.

Roben, P., Moore, J.P., Thali, M., Sodroski, J., Barbas, C.F., 3rd, and Burton, D.R. (1994). Recognition properties of a panel of human recombinant Fab fragments to the CD4 binding site of gp120 that show differing abilities to neutralize human immunodeficiency virus type 1. J Virol 68, 4821-4828.

Rusconi, S., Moonis, M., Merrill, D.P., Pallai, P.V., Neidhardt, E.A., Singh, S.K., Willis, K.J., Osburne, M.S., Profy, A.T., Jenson, J.C., et al. (1996). Naphthalene sulfonate polymers with CD4-blocking and anti-human immunodeficiency virus type 1 activities. Antimicrob Agents Ch 40, 234-236.

Saphire, E.O., Parren, P.W., Pantophlet, R., Zwick, M.B., Morris, G.M., Rudd, P.M., Dwek, R.A., Stanfield, R.L., Burton, D.R., and Wilson, I.A. (2001). Crystal structure of a neutralizing human IGG against HIV-1: a template for vaccine design. Science 293, 1155-1159.

Scheid, J.F., Mouquet, H., Ueberheide, B., Diskin, R., Klein, F., Oliveira, T.Y., Pietzsch, J., Fenyo, D., Abadir, A., Velinzon, K., et al. (2011). Sequence and structural convergence of broad and potent HIV antibodies that mimic CD4 binding. Science 333, 1633-1637.

Scherer, E.M., Zwick, M.B., Teyton, L., and Burton, D.R. (2007). Difficulties in eliciting broadly neutralizing anti-HIV antibodies are not explained by cardiolipin autoreactivity. Aids 21, 2131-2139.

Seto, M., Aikawa, K., Miyamoto, N., Aramaki, Y., Kanzaki, N., Takashima, K., Kuze, Y., lizawa, Y., Baba, M., and Shiraishi, M. (2006). Highly potent and orally active CCR5 antagonists as anti-HIV-1 agents: synthesis and biological activities of 1-benzazocine derivatives containing a sulfoxide moiety. J Med Chem 49, 2037-2048.

Shearer, W.T., Israel, R.J., Starr, S., Fletcher, C.V., Wara, D., Rathore, M., Church, J., DeVille, J., Fenton, T., Graham, B., et al. (2000). Recombinant CD4-lgG2 in human immunodeficiency virus type 1-infected children: phase $1 / 2$ study. The Pediatric AIDS Clinical Trials Group Protocol 351 Study Team. J Infect Dis 182, 1774-1779.

Shimizu, S., Hong, P., Arumugam, B., Pokomo, L., Boyer, J., Koizumi, N., Kittipongdaja, P., Chen, A., Bristol, G., Galic, Z., et al. (2010). A highly efficient short hairpin RNA potently down-regulates CCR5 expression in systemic lymphoid organs in the hu-BLT mouse model. Blood 115, 1534-1544.

Si, Z., Madani, N., Cox, J.M., Chruma, J.J., Klein, J.C., Schon, A., Phan, N., Wang, L., Biorn, A.C., Cocklin, S., et al. (2004). Small-molecule inhibitors of HIV-1 entry block receptor-induced conformational changes in the viral envelope glycoproteins. Proc Natl Acad Sci U S A, 101, 5036-5041.

Sierra-Madero, J., Di Perri, G., Wood, R., Saag, M., Frank, I., Craig, C., Burnside, R., McCracken, J., Pontani, D., Goodrich, J., et al. (2010). Efficacy and safety of maraviroc versus efavirenz, both with zidovudine/lamivudine: 96-week results from the MERIT study. HIV Clin Trials 11, 125-132.

Simmons, G., Clapham, P.R., Picard, L., Offord, R.E., Rosenkilde, M.M., Schwartz, T.W., Buser, R., Wells, T.N., and Proudfoot, A.E. 
(1997). Potent inhibition of HIV-1 infectivity in macrophages and lymphocytes by a novel CCR5 antagonist. Science 276, 276-279.

Smita, J., Soma, D., Beverly, B., Albert, P., JoAnn, K., Fang, G., Missy, C., Lydia, S.T., Anjali, P., Arun, R., et al. (2006). Phase I safety study of $0.5 \%$ PRO 2000 vaginal Gel among HIV un-infected women in Pune, India. AIDS Res Ther 3, 4.

Song, R., Franco, D., Kao, C.Y., Yu, F., Huang, Y., and Ho, D.D. (2010). Epitope mapping of ibalizumab, a humanized anti-CD4 monoclonal antibody with anti-HIV-1 activity in infected patients. $J$ Virol 84, 6935-6942.

Stiegler, G., Kunert, R., Purtscher, M., Wolbank, S., Voglauer, R., Steindl, F., and Katinger, H. (2001). A potent cross-clade neutralizing human monoclonal antibody against a novel epitope on gp41 of human immunodeficiency virus type 1. AIDS Res Hum Retrov 17, 1757-1765.

Strizki, J.M., Tremblay, C., Xu, S., Wojcik, L., Wagner, N., Gonsiorek, W., Hipkin, R.W., Chou, C.C., Pugliese-Sivo, C., Xiao, Y., et al. (2005). Discovery and characterization of vicriviroc (SCH 417690), a CCR5 antagonist with potent activity against human immunodeficiency virus type 1. Antimicrob Agents Ch 49, 4911-4919.

Suleiman, J., Zingman, B.S., Diaz, R.S., Madruga, J.V., DeJesus, E., Slim, J., Mak, C., Lee, E., McCarthy, M.C., Dunkle, L.M., et al. (2010). Vicriviroc in combination therapy with an optimized regimen for treatment-experienced subjects: 48-week results of the VICTOR-E1 phase 2 trial. J Infect Dis 201, 590-599.

Tabet, S.R., Callahan, M.M., Mauck, C.K., Gai, F., Coletti, A.S., Profy, A.T., Moench, T.R., Soto-Torres, L.E., Poindexter, I.A., Frezieres, R.G., et al. (2003). Safety and acceptability of penile application of 2 candidate topical microbicides: BufferGel and PRO 2000 Gel: 3 randomized trials in healthy low-risk men and HIV-positive men. $J$ Acquir Immune Defic Syndr 33, 476-483.

Takashima, K., Miyake, H., Kanzaki, N., Tagawa, Y., Wang, X., Sugihara, Y., lizawa, Y., and Baba, M. (2005). Highly potent inhibition of human immunodeficiency virus type 1 replication by TAK-220, an orally bioavailable small-molecule CCR5 antagonist. Antimicrob Agents Ch 49, 3474-3482.

Tebas, P., Levine, B., Binder, G., Hoxie, J., Collman, R., Gregory, P., Holmes, M., Ando, D., and June, C. (2011). Disruption of CCR5 in Zinc Finger Nuclease-treated CD4 T Cells: Phase I Trials. In XVIII Conference on Retroviruses and Opportunistic Infections (San Francisco, CA, USA).

Teleshova, N., Chang, T., Profy, A., and Klotman, M.E. (2008). Inhibitory effect of PRO 2000, a candidate microbicide, on dendritic cell-mediated human immunodeficiency virus transfer. Antimicrob Agents Ch 52, 1751-1758.

Tilton, J.C., Wilen, C.B., Didigu, C.A., Sinha, R., Harrison, J.E., Agrawal-Gamse, C., Henning, E.A., Bushman, F.D., Martin, J.N., Deeks, S.G., et al. (2010). A maraviroc-resistant HIV-1 with narrow cross-resistance to other CCR5 antagonists depends on both $\mathrm{N}$-terminal and extracellular loop domains of drug-bound CCR5. J Virol 84, 10863-10876.

Tremblay, C.L., Giguel, F., Guan, Y., Chou, T.C., Takashima, K., and Hirsch, M.S. (2005). TAK-220, a novel small-molecule CCR5 antagonist, has favorable anti-human immunodeficiency virus interactions with other antiretrovirals in vitro. Antimicrob Agents Ch 49, 3483-3485.
Tremblay, C.L., Kollmann, C., Giguel, F., Chou, T.C., and Hirsch, M.S. (2000). Strong in vitro synergy between the fusion inhibitor T-20 and the CXCR4 blocker AMD-3100. J Acquir Immune Defic Syndr 25, 99-102.

Trkola, A., Ketas, T.J., Nagashima, K.A., Zhao, L., Cilliers, T., Morris, L., Moore, J.P., Maddon, P.J., and Olson, W.C. (2001). Potent, broad-spectrum inhibition of human immunodeficiency virus type 1 by the CCR5 monoclonal antibody PRO 140. J Virol 75, 579-588.

Trkola, A., Kuster, H., Rusert, P., Joos, B., Fischer, M., Leemann, C., Manrique, A., Huber, M., Rehr, M., Oxenius, A., et al. (2005). Delay of HIV-1 rebound after cessation of antiretroviral therapy through passive transfer of human neutralizing antibodies. Nat Med 11, 615-622.

Trkola, A., Purtscher, M., Muster, T., Ballaun, C., Buchacher, A., Sullivan, N., Srinivasan, K., Sodroski, J., Moore, J.P., and Katinger, H. (1996). Human monoclonal antibody $2 \mathrm{G} 12$ defines a distinctive neutralization epitope on the gp120 glycoprotein of human immunodeficiency virus type $1 . \mathrm{J}$ Virol 70, 1100-1108.

Trottier, B., Walmsley, S., Reynes, J., Piliero, P., O'Hearn, M., Nelson, M., Montaner, J., Lazzarin, A., Lalezari, J., Katlama, C., et al. (2005). Safety of enfuvirtide in combination with an optimized background of antiretrovirals in treatment-experienced HIV-1-infected adults over 48 weeks. J Acquir Immune Defic Syndr 40, 413-421.

Tudor, D., and Bomsel, M. (2011). The broadly neutralizing HIV-1 IgG 2F5 elicits gp41-specific antibody-dependent cell cytotoxicity in a FcgammaRI-dependent manner. Aids 25, 751-759.

UNAIDS. (2010). Global report: UNAIDS report on the global AIDS epidemic 2010 (Geneva, UNAIDS).

Urnov, F.D., Miller, J.C., Lee, Y.L., Beausejour, C.M., Rock, J.M., Augustus, S., Jamieson, A.C., Porteus, M.H., Gregory, P.D., and Holmes, M.C. (2005). Highly efficient endogenous human gene correction using designed zinc-finger nucleases. Nature 435, 646-651.

Vcelar, B., Stiegler, G., Wolf, H.M., Muntean, W., Leschnik, B., Mehandru, S., Markowitz, M., Armbruster, C., Kunert, R., Eibl, M.M., et al. (2007). Reassessment of autoreactivity of the broadly neutralizing HIV antibodies $4 \mathrm{E} 10$ and $2 \mathrm{~F} 5$ and retrospective analysis of clinical safety data. Aids 21, 2161-2170.

Veazey, R.S., Klasse, P.J., Schader, S.M., Hu, Q., Ketas, T.J., Lu, M., Marx, P.A., Dufour, J., Colonno, R.J., Shattock, R.J., et al. (2005). Protection of macaques from vaginal SHIV challenge by vaginally delivered inhibitors of virus-cell fusion. Nature 438, 99-102.

Veazey, R.S., Shattock, R.J., Pope, M., Kirijan, J.C., Jones, J., Hu, Q., Ketas, T., Marx, P.A., Klasse, P.J., Burton, D.R., et al. (2003). Prevention of virus transmission to macaque monkeys by a vaginally applied monoclonal antibody to HIV-1 gp120. Nat Med 9, 343-346.

Walker, L.M., Huber, M., Doores, K.J., Falkowska, E., Pejchal, R., Julien, J.P., Wang, S.K., Ramos, A., Chan-Hui, P.Y., Moyle, M., et al. (2011). Broad neutralization coverage of HIV by multiple highly potent antibodies. Nature 477, 466-470.

Walker, L.M., Phogat, S.K., Chan-Hui, P.Y., Wagner, D., Phung, P., Goss, J.L., Wrin, T., Simek, M.D., Fling, S., Mitcham, J.L., et al. (2009). Broad and potent neutralizing antibodies from an African donor reveal a new HIV-1 vaccine target. Science 326, 285-289. 
Wang, T., Yin, Z., Zhang, Z., Bender, J.A., Yang, Z., Johnson, G., Zadjura, L.M., D'Arienzo, C.J., DiGiugno Parker, D., Gesenberg, C., et al. (2009). Inhibitors of human immunodeficiency virus type 1 (HIV-1) attachment. 5. An evolution from indole to azaindoles leading to the discovery of 1-(4-benzoylpiperazin-1-yl)-2-(4,7-dimethoxy-1H-pyrrolo [2,3-c]pyridin-3-yl) ethane-1,2-dione (BMS488043), a drug candidate that demonstrates antiviral activity in HIV-1-infected subjects. J Med Chem 52, 7778-7787.

Wang, T., Zhang, Z., Wallace, O.B., Deshpande, M., Fang, H., Yang, Z., Zadjura, L.M., Tweedie, D.L., Huang, S., Zhao, F., et al. (2003). Discovery of 4-benzoyl-1-[(4-methoxy-1H- pyrrolo[2,3-b]pyridin3-yl)oxoacetyl]-2- (R)-methylpiperazine (BMS-378806): a novel HIV-1 attachment inhibitor that interferes with CD4-gp120 interactions. J Med Chem 46, 4236-4239.

Watson, C., Jenkinson, S., Kazmierski, W., and Kenakin, T. (2005). The CCR5 receptor-based mechanism of action of 873140 , a potent allosteric noncompetitive HIV entry inhibitor. Mol Pharmacol 67, 1268-1282.

Wei, X., Decker, J.M., Liu, H., Zhang, Z., Arani, R.B., Kilby, J.M., Saag, M.S., Wu, X., Shaw, G.M., and Kappes, J.C. (2002). Emergence of resistant human immunodeficiency virus type 1 in patients receiving fusion inhibitor (T-20) monotherapy. Antimicrob Agents Ch 46, 1896-1905.

West, A.P., Jr., Galimidi, R.P., Foglesong, C.P., Gnanapragasam, P.N., Huey-Tubman, K.E., Klein, J.S., Suzuki, M.D., Tiangco, N.E., Vielmetter, J., and Bjorkman, P.J. (2009). Design and expression of a dimeric form of human immunodeficiency virus type 1 antibody $2 \mathrm{G} 12$ with increased neutralization potency. J Virol 83, 98-104.

Westby, M., Smith-Burchnell, C., Mori, J., Lewis, M., Mosley, M., Stockdale, M., Dorr, P., Ciaramella, G., and Perros, M. (2007). Reduced maximal inhibition in phenotypic susceptibility assays indicates that viral strains resistant to the CCR5 antagonist maraviroc utilize inhibitor-bound receptor for entry. J Virol 81, 2359-2371.

Wild, C., Greenwell, T., and Matthews, T. (1993). A synthetic peptide from HIV-1 gp41 is a potent inhibitor of virus-mediated cell-cell fusion. AIDS Res Hum Retrov 9, 1051-1053.

Wilen, C., Wang, J., Tilton, J., Miller, J., Sherrill-Mix, S., Bushman, F., Gregory, P., June, C., Holmes, M., and Doms, R. (2011). Creating an HIV-resistant immune system: using CXCR4 ZFN to edit the human genome. In XVIII Conference on Retroviruses and Opportunistic Infections (San Francisco, CA, USA).
Wilkin, T.J., Su, Z., Krambrink, A., Long, J., Greaves, W., Gross, R., Hughes, M.D., Flexner, C., Skolnik, P.R., Coakley, E., et al. (2010). Three-year safety and efficacy of vicriviroc, a CCR5 antagonist, in HIV-1-infected treatment-experienced patients. J Acquir Immune Defic Syndr 54, 470-476.

Witvrouw, M., Pannecouque, C., Switzer, W.M., Folks, T.M., De Clercq, E., and Heneine, W. (2004). Susceptibility of HIV-2, SIV and SHIV to various anti-HIV-1 compounds: implications for treatment and postexposure prophylaxis. Antivir Ther 9, 57-65.

Wu, X., Yang, Z.Y., Li, Y., Hogerkorp, C.M., Schief, W.R., Seaman, M.S., Zhou, T., Schmidt, S.D., Wu, L., Xu, L., et al. (2010). Rational design of envelope identifies broadly neutralizing human monoclonal antibodies to HIV-1. Science 329, 856-861.

Wu, X., Zhou, T., O'Dell, S., Wyatt, R.T., Kwong, P.D., and Mascola, J.R. (2009). Mechanism of human immunodeficiency virus type 1 resistance to monoclonal antibody $\mathrm{B} 12$ that effectively targets the site of CD4 attachment. J Virol 83, 10892-10907.

Wu, X., Zhou, T., Zhu, J., Zhang, B., Georgiev, I., Wang, C., Chen, X., Longo, N.S., Louder, M., McKee, K., et al. (2011). Focused evolution of HIV-1 neutralizing antibodies revealed by structures and deep sequencing. Science 333, 1593-1602.

Zhang, X.Q., Sorensen, M., Fung, M., and Schooley, R.T. (2006). Synergistic in vitro antiretroviral activity of a humanized monoclonal anti-CD4 antibody (TNX-355) and enfuvirtide (T-20). Antimicrob Agents Ch 50, 2231-2233.

Zhou, N., Nowicka-Sans, B., Zhang, S., Fan, L., Fang, J., Fang, H., Gong, Y.F., Eggers, B., Langley, D.R., Wang, T., et al. (2011). In vivo patterns of resistance to the HIV attachment inhibitor BMS-488043. Antimicrob Agents Ch 55, 729-737.

Zhou, T., Georgiev, I., Wu, X., Yang, Z.Y., Dai, K., Finzi, A., Kwon, Y.D., Scheid, J.F., Shi, W., Xu, L., et al. (2010). Structural basis for broad and potent neutralization of HIV-1 by antibody VRC01. Science 329, 811-817.

Zwick, M.B., Labrijn, A.F., Wang, M., Spenlehauer, C., Saphire, E.O., Binley, J.M., Moore, J.P., Stiegler, G., Katinger, H., Burton, D.R., et al. (2001a). Broadly neutralizing antibodies targeted to the membrane-proximal external region of human immunodeficiency virus type 1 glycoprotein gp41. J Virol 75, 10892-10905.

Zwick, M.B., Wang, M., Poignard, P., Stiegler, G., Katinger, H., Burton, D.R., and Parren, P.W. (2001b). Neutralization synergy of human immunodeficiency virus type 1 primary isolates by cocktails of broadly neutralizing antibodies. J Virol 75, 12198-12208. 